\title{
Competing Presumptions About Statutory Coherence
}

\section{Citation}

John F. Manning, Competing Presumptions About Statutory Coherence, 74 Fordham L. Rev. 2009 (2006).

\section{Published Version}

http://ir.lawnet.fordham.edu/flr/vol74/iss4/15/

\section{Permanent link}

http://nrs.harvard.edu/urn-3:HUL.InstRepos:12956318

\section{Terms of Use}

This article was downloaded from Harvard University's DASH repository, and is made available under the terms and conditions applicable to Other Posted Material, as set forth at http:// nrs.harvard.edu/urn-3:HUL.InstRepos:dash.current.terms-of-use\#LAA

\section{Share Your Story}

The Harvard community has made this article openly available.

Please share how this access benefits you. Submit a story.

Accessibility 


\section{Fordham Law Review}

Volume 74 | Issue 4

Article 15

2006

\section{Competing Presumptions About Statutory Coherence}

John F. Manning

\section{Recommended Citation}

John F. Manning, Competing Presumptions About Statutory Coherence, 74 Fordham L. Rev. 2009 (2006).

Available at: http://ir.lawnet.fordham.edu/flr/vol74/iss4/15

This Article is brought to you for free and open access by FLASH: The Fordham Law Archive of Scholarship and History. It has been accepted for inclusion in Fordham Law Review by an authorized administrator of FLASH: The Fordham Law Archive of Scholarship and History. For more

information, please contact tmelnick@law.fordham.edu. 


\title{
COMPETING PRESUMPTIONS ABOUT STATUTORY COHERENCE
}

\author{
John F. Manning*
}

\section{INTRODUCTION}

In marking the beginning of Justice John Paul Stevens's fourth decade on the Supreme Court of the United States, one could not in good conscience omit discussion of his philosophy of statutory interpretation. For some time now, Justice Stevens has been the Court's most vocal and, I believe, the ablest defender of what two generations of judges and lawyers took to be the post-New Deal consensus on statutory interpretation: the idea that legislation is a purposive act, and that judges should interpret acts of Congress to implement the legislative purpose, even if doing so requires some deviation from the semantic detail of the enacted text. ${ }^{1}$ The basis for his position-which, until recently, was also the Court's ${ }^{2}$-is familiar. Justice Stevens starts from the faithful agent theory; he believes that the federal courts in our system must discern and apply Congress's intended meaning as accurately as possible. ${ }^{3}$ He also falls within a deeply rooted intellectual tradition that emphasizes the fallibility of legislative

* Professor of Law, Harvard Law School. I thank David Barron, Bradford Clark, Daniel Farber, Philip Frickey, Debra Livingston, and Henry Monaghan for insightful suggestions. I am grateful to the participants of the Fordham Law School conference on the Jurisprudence of Justice Stevens for thoughtful and stimulating comments on the paper.

1. In United States v. American Trucking Ass'ns, 310 U.S. 534, 543-44 (1940), the Court offered a highly influential description of that practice:

When [plain] meaning has led to absurd or futile results ... this Court has looked beyond the words to the purpose of the act. Frequently, however, even when the plain meaning did not produce absurd results but merely an unreasonable one "plainly at variance with the policy of the legislation as a whole" this Court has followed that purpose, rather than the literal words. When aid to construction of the meaning of words, as used in the statute, is available, there certainly can be no "rule of law" which forbids its use, however clear the words may appear on "superficial examination."

2. See infra note 87 (citing cases establishing the orthodoxy prior to the Rehnquist Court); see also infra text accompanying notes 109-16 (discussing the shift in prevailing interpretive norms during the Rehnquist Court).

3. See United States v. Wells, 519 U.S. 482, 510-11 (1997) (Stevens, J., dissenting) ("Even the Court's recent jurisprudence affirms that ' $[t]$ he purpose of Congress is the ultimate touchstone."' (quoting Gade v. Nat'l Solid Wastes Mgmt. Ass'n, 505 U.S. 88, 96 (1992))); Griffin v. Oceanic Contractors, Inc., 458 U.S. 564, 577 (1982) (Stevens, J., dissenting) ("In final analysis, any question of statutory construction requires the judge to decide how the legislature intended its enactment to apply to the case at hand."). 
expression. ${ }^{4}$ Limits on human foresight, imprecision in the tools of linguistic expression, and constraints on legislative resources contribute to the production of generally worded texts that could not possibly capture the variety of situations that lie ahead. If a statute's semantic detail produces an outcome that appears unreasonable in light of the law's background purpose (often, as reflected in the legislative history), Justice Stevens assumes that Congress spoke clearly but inaccurately in choosing the words to express its aims. In other words, he presumes that Congress is (understandably) error prone in linguistic expression but quite coherent in the substantive framing of policies that serve some overarching purpose. For Justice Stevens, respect for Congress means fidelity to that purpose rather than to the oftenfaulty semantic details of whatever text it happened to adopt.

In the past two decades, Justice Stevens has fought what is largely a rearguard action in defense of post-war purposivism. In matters of statutory interpretation, the story of the Rehnquist Court was, if anything, one of movement toward textualism-a philosophy that gives precedence to a statute's semantic meaning, when clear, and eschews reliance on legislative history or other indicia of background purpose to vary the conventional meaning of the text. ${ }^{5}$ Justice Antonin Scalia, whose appointment coincided with the advent of the Rehnquist Court, has been the most influential exponent of the Court's new (or, he would argue, renewed) emphasis on the conventional semantic import of the text. The design of the legislative process emphasizes the need for compromise, and compromises are often complex, awkward, and even incoherent-thus making it dangerous for judges to smooth over the details of an agreed-upon text to make it more coherent with its perceived purpose. On that view, judges should hew closely to the semantic import of what Congress as a whole has been able to agree upon through the opaque and path-dependent processes for adopting a statutory text; they should not try to improve upon the end product by superimposing an almost surely counterfactual presumption of reasonable coherence with some hypothesized background purpose. Justice Scalia's vision of Congress thus presumes that it is quite deliberate in statutory expression, but (understandably) quite messy in the substantive policies it adopts. For him, respect for Congress means accepting the semantic import (when clear) of whatever text in fact surmounted the high hurdles of a legislative process designed to make it hard to adopt statutes and easy for legislative gatekeepers to insist upon compromise as the price of assent.

This Essay will compare these rival presumptions, trying to cast each in its most sympathetic light, and then will suggest why the textualists' presumption of untidy compromise fits more comfortably with legislative process assumptions derived from the constitutional structure. In Part I, I elaborate on the premises about legislation that Justice Stevens brings to the

4. The discussion that follows builds upon John F. Manning, Textualism and the Equity of the Statute, 101 Colum. L. Rev. 1, 10-15 (2001).

5. See infra text accompanying notes 109-16. 
practice of purposivism. In particular, I note that Justice Stevens equates respect for the legislative process with the presumption that legislatures act reasonably. For him, sharp textual deviations from reasonable coherence presumably reflect legislative misstatement rather than design. Part II examines Justice Scalia's competing premise that the legislative process often entails messy and untraceable compromise. For him, respect for that process entails the assumption that oddities in textual outcome reflect such compromise. In both parts I supplement the Justices' writing with the often more elaborate analyses of the legislative process written by their respective intellectual allies on the United States Court of Appeals for the Seventh Circuit-Judge Richard Posner in the case of Justice Stevens, and Judge Frank Easterbrook in Justice Scalia's case.

In Part III, I disclose my own (scarcely concealed) sympathies for textualism. In particular, I explain that given the complexity and opacity of the legislative process, neither Justice Stevens nor Justice Scalia has empirical basis for concluding in any given case that awkwardness in a statute's means/ends fit is reliably traceable to either mistaken legislative expression or unrecorded compromise. Accordingly, equating respect for Congress with one presumption or the other ultimately must depend on identifying some systemic, normatively rooted premise that ultimately derives from the constitutional structure. Building on earlier writing, I argue in Part III.A that the presumption of deliberate drafting but untidy compromise is more respectful of the central place of compromise in the constitutional design of the legislative process. ${ }^{6}$ In particular such a presumption enables legislators to rely on semantic detail to express the level of generality at which a proposed legislative policy is acceptable to them. If the Court presumes that awkward statutory outcomes typically reflect mistaken expression, then legislators cannot reliably use the only effective tool at their disposal-the phrasing of a statutory command-to express limits upon the legislative policy to which they are willing to assent. Part III.B, in turn, argues that a background interpretive presumption of messy legislative compromise rather than drafting error is more consistent with the legislative and judicial process assumptions that underlie the modern rational-basis test, which defines the default position under the Due Process and Equal Protection Clauses for judicial review of ordinary social and economic legislation (viz. legislation that does not implicate suspect classifications or fundamental rights). The Court has repeatedly admonished that judges in our system of government must uphold legislation that has any conceivable rational basis, lest they substitute their own conception of wise and coherent legislative policy for the untidy results of the democratic process. An assertion of authority to displace insufficiently coherent statutory classifications in the name of purposive interpretation authorizes judges to do indirectly what the rationalbasis cases forbid them to do directly. For these reasons, even though it 
may be realistically impossible to know in any case whether an awkward statutory application reflects legislative error (as Justice Stevens would have it) or compromise (as Justice Scalia might claim), salient features of our constitutional structure suggest that judges should apply a presumption of messy compromise rather than scrivener's error.

\section{Justice Stevens and the Presumption of COHERENT Policy MAKING BUT MESSY DRAFTING}

Justice Stevens has long held the view that interpreters should presume that Congress pursues relatively coherent policy objectives but often expresses those policies imprecisely. In that sense, he writes in the tradition of Church of the Holy Trinity v. United States, ${ }^{7}$ which stands for the familiar principle that the text of a statute, however clear, must yield to its purpose when the latter is clear. ${ }^{8}$ The facts are familiar to those who have followed the statutory interpretation debate in recent years. The Contract Labor Act had made it a crime to assist or encourage any alien to migrate to the United States to " "perform labor or service of any kind." The church had contracted with a cleric, E. Walpole Warren, to move from England to minister to a New York congregation, and the Court acknowledged that doing so transgressed the express terms of the Act's textual prohibition. ${ }^{10}$ The Court, however, held that "a thing may be within the letter of the statute and yet not within the statute, because not within its spirit, nor within the intention of its makers." 11 In particular, the Court found that the statute's background purpose was to prevent the migration of manual laborers rather than "brain toilers" like Reverend Warren. The Act's title only mentioned those who came "to perform labor,"12 and the circumstances surrounding the Act's passage, including the legislative history, further suggested that Congress sought only to prevent "the influx

7. 143 U.S. 457 (1892).

8. Indeed, in more than a decade and a half, only opinions written by Justice John Paul Stevens have cited Holy Trinity affirmatively for the crucial interpretive principle that it has come to represent. See Dodd v. United States, 125 S. Ct. 2478, 2488 (2005) (Stevens, J., dissenting); Chapman v. United States, 500 U.S. 453, 476 (1991) (Stevens, J., dissenting).

9. Holy Trinity, 143 U.S. at 458 (quoting 23 Stat. 332 (1885)).

10. The Holy Trinity Court acknowledged that the church's action had violated the letter of the law. See id. at 458-59. In Holy Trinity, the Court wrote as follows:

It must be conceded that the act of the corporation is within the letter of this section, for the relation of rector to his church is one of service, and implies labor on the one side with compensation on the other. Not only are the general words "labor" and "service" both used, but also, as it were to guard against any narrow interpretation and emphasize a breadth of meaning, to them is added "of any kind;" and, further ... the fifth section [of the statute], which makes specific exceptions, among them professional actors, artists, lecturers, singers, and domestic servants, strengthens the idea that every other kind of labor and service was intended to be reached.

Id.

11. Id. at 459 .

12. Id. at 463 . 
of . . cheap unskilled labor."13 And, of course, the Court famously noted that given the commonly held and deeply rooted religious values of the populace, judges should not assume that the nation's representatives would have intended to prohibit the immigration of clergy had the question arisen expressly during the legislature's deliberations. ${ }^{14}$ Based on all of those contextual circumstances, the Court found it "unreasonable to believe that the legislat[ure] intended to include the particular act" of hiring a minister from abroad. ${ }^{15}$ Instead, the Court concluded that the enacted text "unexpectedly ... reach[ed] cases and acts which . . could not have been intentionally legislated against."16 So bringing the text into line with its purpose was not "the substitution of the will of the judge for that of the legislator," 17 but rather a superior way to fulfill the Court's duty as a faithful congressional agent.

Justice Stevens subscribes to this approach. He believes that a faithful agent must follow his or her principal's purpose rather than phraseology in

13. Id. at 465 . The Court laid particular emphasis on a Senate Report, which explained as follows:

The general facts and considerations which induce the committee to recommend the passage of this bill are set forth in the Report of the Committee of the House. The committee report the bill back without amendment, although there are certain features thereof which might well be changed or modified, in the hope that the bill may not fail of passage during the present session. Especially would the committee have otherwise recommended amendments, substituting for the expression "labor and service," whenever it occurs in the body of the bill, the words "manual labor" or "manual service," as sufficiently broad to accomplish the purposes of the bill, and that such amendments would remove objections which a sharp and perhaps unfriendly criticism may urge to the proposed legislation. The committee, however, believing that the bill in its present form will be construed as including only those whose labor or service is manual in character, and being very desirous that the bill become a law before the adjournment, have reported the bill without change.

Id. at 464-65 (citation omitted). For an excellent analysis suggesting that the Court misread this legislative history see Adrian Vermeule, Legislative History and the Limits of Judicial Competence: The Untold Story of Holy Trinity Church, 50 Stan. L. Rev. 1833, 1845-50 (1998).

14. The Court explained as follows:

Suppose in the Congress that passed this act some member had offered a bill which in terms declared that, if any Roman Catholic church in this country should contract with Cardinal Manning to come to this country and enter into its service as pastor and priest; or any Episcopal church should enter into a like contract with Canon Farrar; or any Baptist church should make similar arrangements with Rev. Mr. Spurgeon; or any Jewish synagogue with some eminent Rabbi, such contract should be adjudged unlawful and void, and the church making it be subject to prosecution and punishment, can it be believed that it would have received a minute of approving thought or a single vote? Yet it is contended that such was in effect the meaning of this statute. The construction invoked cannot be accepted as correct.

Holy Trinity, 143 U.S. at 472 ; see also id. at 465 ("[N]o purpose of action against religion can be imputed to any legislation, state or national, because this is a religious people.").

15. Id. at 459.

16. Id. at 472 .

17. Id. at 459 . 
cases in which the conventional meaning of a text makes little sense of the purposes that apparently inspired it. ${ }^{18}$ There is much to be said for this position. It is undeniable that all laws are over-inclusive or under-inclusive relative to their background justifications. Indeed, the more precisely drafted the law, the more likely it is to reflect such problems of fit. ${ }^{19}$ As Justice Stevens has thus acknowledged, the superficial semantic clarity of a text may be " the consequence of a legislative accident, perhaps caused by nothing more than the unfortunate fact that Congress is too busy to do all of its work as carefully as it should." 20 Or, put another way, "legislative oversight or inadvertence can at times produce statutory language that does not cleanly reflect Congress' intention." 21

This emphasis on the possibility of legislative inadvertence puts Justice Stevens in good company. Thinkers no less consequential than Aristotle, ${ }^{22}$ Blackstone, ${ }^{23}$ and Madison $^{24}$ all recognized the inherent difficulties of accurate legislative expression. And an important strand of modern

18. See infra Parts I.A-C.

19. See, e.g., Colin S. Diver, The Optimal Precision of Administrative Rules, 93 Yale L.J. 65, 73 (1983) ("Increasing the transparency of a rule may increase the variance between intended and actual outcomes. The rulemaker may be unable to predict every consequence of applying the rule or to foresee all the circumstances to which it may apply."); Louis Kaplow, Rules Versus Standards: An Economic Analysis, 42 Duke L.J. 557, 591 (1992) ("T] $T$ he simple rule is both over- and underinclusive compared to the more complex standard.").

20. United States v. Locke, 471 U.S. 84, $118-19$ (1985) (Stevens, J., dissenting) (emphasis omitted) (quoting Del. Tribal Bus. Comm. v. Weeks, 430 U.S. 73, 97 (1977) (Stevens, J., dissenting)).

21. Pittston Coal Group v. Sebben, 488 U.S. 105, 145 n.10 (1988) (Stevens, J., dissenting).

22. Aristotle wrote as follows:

When the law speaks universally ... and a case arises on it which is not covered by the universal statement, then it is right, where the legislator fails us and has erred by oversimplicity, to correct the omission - to say what the legislator himself would have said had he been present, and would have put into his law if he had known.

Aristotle, V Nichomachean Ethics 10:19-24 (W.D. Ross trans., 1925).

23. Blackstone explained:

[S]ince in laws all cases cannot be foreseen or expressed, it is necessary, that when the general decrees of the law come to be applied to particular cases, there should be somewhere a power vested of defining those circumstances, which (had they been foreseen) the legislator himself would have expressed.

William Blackstone, 1 Commentaries *62.

24. See The Federalist No. 37, at 225 (James Madison) (Clinton Rossiter ed., 1961). Madison thus emphasized:

All new laws, though penned with the greatest technical skill and passed on the fullest and most mature deliberation, are considered as more or less obscure and equivocal, until their meaning be liquidated and ascertained by a series of particular discussions and adjudications. Besides the obscurity arising from the complexity of objects and the imperfection of the human faculties, the medium through which the conceptions of men are conveyed to each other adds a fresh embarrassment.

Id. In contrast with Aristotle and Blackstone, Madison acknowledged the difficulty but did not urge interpretation in contravention of the clear semantic import of the text. 
language theory, known as pragmatics, rests on the compatible premise that because human beings sometimes express themselves inaccurately, listeners in a cooperative setting must occasionally tweak the literal meaning of what has been said in order to make sense of an utterance in context. ${ }^{25}$

In modern times, no one has encapsulated the common sense of this idea more clearly than Judge Posner, whose interpretive philosophy aligns quite closely with that of Justice Stevens. ${ }^{26}$ Posner has written that it is only natural for judges to adjust the semantic import of a statutory text when there is a mismatch between its conventional meaning and the statute's background aims:

[J]udges realize in their heart of hearts that the superficial clarity to which they are referring when they call the meaning of a statute "plain" is treacherous footing for interpretation. They know that statutes are purposive utterances and that language is a slippery medium in which to encode a purpose. They know that legislatures, including the Congress of

25. Language philosopher Paul Grice thus argues that conversations are typically cooperative enterprises and that the norms of communication should follow from that premise. See Paul Grice, Studies in the Way of Words 26 (1989). Grice then deduces several maxims to implement this "Cooperative Principle." Id. These commonsense norms of conversation include the following: "Make your contribution as informative as is required" (quantity); "[t]ry to make your contribution one that is true" (quality); "[b]e relevant" (relation); and "[a]void obscurity of expression" (manner). Id. at 26-27. Grice believes that if a speaker apparently flouts the cooperative principle, a listener may sometimes properly assign an unconventional meaning to the utterance, interpreting it as if the cooperative principle had been observed. Id at $30-31$. Recent legal scholarship has sought to rely on the cooperative principle to justify atextual, purposive interpretation of the type practiced by Justice Stevens. See, e.g., Geoffrey P. Miller, Pragmatics and the Maxims of Interpretation, 1990 Wis. L. Rev. 1179, 1211 (arguing that if conventional meaning of a statute disserves its apparent background purpose, then interpreting the statute as written would violate the cooperative principle by assuming that "Congress was either deceptive or lacked sufficient evidence for the presupposition" that the command served its goals); M.B.W. Sinclair, Law and Language: The Role of Pragmatics in Statutory Interpretation, 46 U. Pitt. L. Rev. 373, $397-99$ (1985) (invoking the maxim of quality to explain the strongly purposive methods of interpretation).

26. Justice Stevens often invokes Judge Posner in support of his interpretive conclusions. See, e.g., Chapman v. United States, 500 U.S. 453, 475 (1991) (Stevens, J., dissenting) ("'This is a quilt the pattern whereof no one has been able to discern. The legislative history is silent, and since even the Justice Department cannot explain the why of the punishment scheme that it is defending, the most plausible inference is that Congress simply did not realize how LSD is sold."' (quoting United States v. Marshall, 908 F.2d 1312, 1333 (7th Cir. 1990) (en banc) (Posner, J., dissenting), rev'd sub nom., Chapman v. United States, 500 U.S. 453 (1991))); Pittston Coal Group, 488 U.S. at 145 n.10 (Stevens, J., dissenting) ("Interpretation is no less a valid method of acquiring knowledge because it necessarily ranges beyond the text."' (quoting Richard A. Posner, Legal Formalism, Legal Realism, and the Interpretation of Statutes and the Constitution, 37 Case W. Res. L. Rev. 179, 191 (1986))); McNally v. United States, 483 U.S. 350, 373 (1987) (Stevens, J., dissenting) (rejecting as "untenable" the contention "that the meaning of fraud in the mailfraud statute was frozen by the conception of fraud held by the framers of the statute when it was first passed back in the nineteenth century" (quoting United States v. Holzer, 816 F.2d 304, 310 (7th Cir. 1987) (Posner., J.))). 
the United States, often legislate in haste, without considering fully the potential application of their words to novel settings. ${ }^{27}$

Starting from that assumption, Judge Posner thinks it only common sense for a subordinate to implement the purpose rather than the semantic meaning of a superior's command: 'Suppose I ask my secretary to call $Z$ [to cancel lunch]. The secretary notices that on my calendar I have marked lunch with $Y$, not $Z$... Is it not plain that the secretary should call $Y$, even though there was no semantic or internal ambiguity in my instruction?"28 By the same token, he writes:

When a court can figure out what Congress probably was driving at and how its goal can be achieved, it is not usurpation-it is interpretation in a sense that has been orthodox since Aristotle-for the court to complete (not enlarge) the statute by reading it to bring about the end that the legislators would have specified had they thought about it more clearly or used a more perspicuous form of words. ${ }^{29}$

The foregoing passages are worth quoting here precisely because, as I now attempt to demonstrate, they nicely capture the jurisprudence of Justice Stevens. In substantiating this claim, my objective is not to catalogue the countless interpretation decisions that Justice Stevens has issued in the past three decades. Rather, three famous opinions-all dissents and thus free of the diluting effects of judicial compromise - exemplify that philosophy and offer a preliminary basis to evaluate its merits and demerits. I ask for the reader's patience here. In selecting the examples that follow, I have focused on cases that involve relatively technical questions, rather than "hot button" issues with potentially distracting political or policy implications.

27. Friedrich v. City of Chicago, 888 F.2d 511, 514 (7th Cir. 1989).

28. Richard A. Posner, The Problems of Jurisprudence 268 (1990). Along similar lines, Professor Lon Fuller famously argued as follows:

No superior wants a servant who lacks the capacity to read between the lines. The stupidest housemaid knows that when she is told "to peel the soup and skim the potatoes" her mistress does not mean what she says. She also knows that when her master tells her to "drop everything and come running" he has overlooked the possibility that she is at the moment in the act of rescuing the baby from the rain barrel. Surely we have a right to expect the same modicum of intelligence from the judiciary. The correction of obvious legislative errors or oversights is not to supplant the legislative will, but to make that will effective.

Lon L. Fuller, The Case of the Speluncean Explorers, 62 Harv. L. Rev. 616, 625-26 (1949).

29. Friedrich, 888 F.2d at 514. For Judge Posner, a judge who insists on enforcing a textual command that does not make sense of its underlying purpose is no better than a soldier who, "having received an order that is clear, but also clearly erroneous because of a mistake in transmission, nevertheless carries out the order as received, rather than trying to determine what response would advance the common enterprise." Posner, supra note 26, at 205; see also Daniel A. Farber, Statutory Interpretation and Legislative Supremacy, 78 Geo. L.J. 281, 289 (1989) ("[L]iteral application of a directive might be senseless or contrary to its obvious purpose. . . Rejecting the literal application in these situations can hardly be considered disobedience."). 


\section{A. Mining Claims}

In United States $v$. Locke, ${ }^{30}$ the Court considered a provision of the Federal Land Policy Management Act of 1976 requiring holders of certain mining claims to record their claims "prior to December 31 " of each year following the year of initial recording. ${ }^{31}$ The claimants in Locke had filed on December 31, and the Bureau of Land Management ("BLM") found that their claims had therefore been abandoned as untimely. ${ }^{32}$ In sustaining the agency's decision, the Court reasoned simply that the meaning of "prior to December 31" was clear, and that "deadlines" by nature require "a literal reading of Congress' words" because they are intrinsically arbitrary. ${ }^{33}$ Further, the Court added that "deference to the supremacy of the Legislature, as well as recognition that Congressmen typically vote on the language of a bill" generally compelled it to assume that the ordinary meaning of the statutory text captured the legislative purpose. ${ }^{34}$

Justice Stevens dissented. In particular, looking at the nature of the scheme, he emphasized that it was obviously designed to require "periodic filings on a calendar-year basis." 35 While acknowledging that the text of the statute did not "correctly describe[]" the end of the calendar year, he found it "understandable that the author [of the statute] might inadvertently use the words 'prior to December 31' when he meant to refer to the end of the calendar year." 36 Various other provisions of the statute contained anomalies that could not be explained except as scrivener's errors, ${ }^{37}$ and an earlier pamphlet issued by the BLM itself had (mis)read the statutory filing deadline in precisely the way the claimants had. ${ }^{38}$ Most important, Justice Stevens found it "rather clear" that the statute's use of "prior to December 31 " "was in fact an error ... because no one has suggested any rational basis for omitting just one day from the period in which an annual filing may be made, and I would not presume that Congress deliberately created a trap for the unwary by such an omission."39 In other words, Justice Stevens treated the mining claims statute as a coherent but poorly expressed end-ofthe-calendar-year deadline and enforced that purpose rather than the (relatively clear) semantic detail.

30. 471 U.S. 84 (1985).

31. 43 U.S.C. $\S 1744$ (a) (1982).

32. Locke, 471 U.S. at 90.

33. Id. at 93 .

34. Id. at 95 .

35. Id. at 123 (Stevens, J., dissenting).

36. $I$.

37. Among them was the following anomaly noted by Judge Posner in an influential article on statutory interpretation:

Further evidence of inadvertence in the use of "prior to" is that the same section of the statute distinguishes between claims "located prior to October 21, 1976" and claims "located after October 21, 1976," thus leaving a void for claims located on October 21, 1976-if "prior to" is read literally.

Posner, supra note 26, at 204.

38. Locke, 471 U.S. at 120-22 (Stevens, J., dissenting).

39. Id. at 123. 


\section{B. Expert Fees}

In West Virginia University Hospitals, Inc. v. Casey, ${ }^{40}$ the Court divided over the meaning of 42 U.S.C. $\S 1988$, which provides that prevailing plaintiffs in certain types of civil rights actions are entitled to recover "a reasonable attorney's fee as part of the costs." 41 The plaintiff had sought to recover as part of his $\S 1988$ "attorney's fees" the fees of experts hired to help prepare the lawsuit and to testify at trial. ${ }^{42}$ Although the Court had previously recognized that the phrase "attorney's fee" constitutes a term of the trade that includes items essential to legal representation (such as charges for paralegal services, secretarial services, messengers, photocopying, and so forth), ${ }^{43}$ the Casey Court found specific evidence of congressional usage that foreclosed treating "expert fees" in the same vein. ${ }^{44}$ In particular, countless other fee-shifting statutes-some enacted before and some after $\S 1988$ - had explicitly provided for "attorney's fees" and "expert fees" as separate items of recovery. ${ }^{45}$ Under the maxim expressio unius est exclusio alterius, " it is generally presumed that Congress acts intentionally and purposely in the disparate inclusion or exclusion"" of particular statutory language. ${ }^{46}$ Accordingly, the Casey Court found that the relevant "statutory usage shows beyond question that attorney's fees and expert fees are distinct items of expense." 47

Justice Stevens dissented. Although acknowledging that Congress had made explicit provision for "attorney's fees" and "expert fees" in "many other statutes," the question for him was "whether, notwithstanding the omission of such an express authorization in 42 U.S.C. $\S 1988$, Congress intended to authorize such recovery." 48 For several reasons, he concluded that Congress had so intended. First, Justice Stevens reasoned that if a

40. 499 U.S. 83 (1991).

41. 42 U.S.C. $\$ 1988(b)(1988)$.

42. Casey, 499 U.S. at 85.

43. See Missouri v. Jenkins, 491 U.S. 274, 285-86 (1989) (holding that various items other than billable attorney hours, including paralegal fees, could be recovered as "traditional" elements of an attorney's fees). The Court there rested on the conventional understanding of the elements of an attorney's fee:

[T] he fee must take into account the work not only of attorneys, but also of secretaries, messengers, librarians, janitors, and others whose labor contributes to the work product for which an attorney bills her client; and it must also take account of other expenses and profit. The parties have suggested no reason why the work of paralegals should not be similarly compensated, nor can we think of any. We thus take as our starting point the self-evident proposition that the "reasonable attorney's fee" provided for by statute should compensate the work of paralegals, as well as that of attorneys. Id. at 285 .

44. Casey, 499 U.S. at 88.

45. Justice Scalia's opinion for the Court in Casey relied specifically on that disparity in denying the recovery of expert fees under $\$ 1988$. Id. at 88-90.

46. Russello v. United States, 464 U.S. 16, 23 (1983) (quoting United States v. Wong Kim Bo, 472 F.2d 720, 722 (5th Cir. 1972)).

47. Casey, 499 U.S. at 92.

48. Id. at 103 (Stevens, J., dissenting). 
prevailing plaintiff could recover a reasonable "attorney's fee," it made no sense to deny the plaintiff similar recovery for an expert, whose services merely provided a lower cost substitute for attorney time. ${ }^{49}$ Second, because the Court had previously recognized that a prevailing plaintiff could recover other non-attorney costs of legal representation under $\S 1988$, it would surely be arbitrary to exclude the fees of experts used to make the legal representation effective. ${ }^{50}$ Third, the legislative history indicatedand the sequence of events, in any case, made clear-that Congress had enacted $\S 1988$ to overturn Alyeska Pipeline Service Co. v. Wilderness Society, ${ }^{51}$ which had rejected the federal courts' earlier common law practice of shifting litigation costs in certain federal cases. Because the preAlyeska regime had shifted attorney's fees and expert fees, Justice Stevens thought it fair to infer that $\S 1988$ 's purpose was to restore the status quo ante. ${ }^{52}$ Fourth, and most generally, "the record of House and Senate subcommittee hearings, consisting of the testimony and written submissions of public officials, scholars, practicing attorneys, and private citizens, and the questions of the legislators, [made] clear that both committees were concerned with preserving access to the courts and encouraging public interest litigation." 53 For Justice Stevens, denying expert fees was "at war with the [resultant] congressional purpose of making the prevailing party whole" for the costs of such litigation. ${ }^{54}$

In closing, Justice Stevens emphasized that "the Court has vacillated between a purely literal approach to the task of statutory interpretation and an approach that seeks guidance from historical context, legislative history, and prior cases identifying the purpose that motivated the legislation." $55 \mathrm{He}$ then observed that in cases in which the Court "put on its thick grammarian's spectacles and ignored the available evidence of congressional purpose and the teaching of prior cases construing a statute," Congress has been swift to revise the underlying statute to reject the Court's interpretation. ${ }^{56}$ Starting from that premise, Justice Stevens summed up his basic philosophy of interpretation as follows:

In the domain of statutory interpretation, Congress is the master. It obviously has the power to correct our mistakes, but we do the country a disservice when we needlessly ignore persuasive evidence of Congress' actual purpose and require it "to take the time to revisit the matter" and to restate its purpose in more precise English whenever its work product

49. See id. at 106-07.

50. Id. at 107-08 ("To allow reimbursement of these other categories of expenses, and yet not to include expert witness fees, is both arbitrary and contrary to the broad remedial purpose that inspired the fee-shifting provision of $\S 1988$.").

51. 421 U.S. 240 (1975).

52. See Casey, 499 U.S. at 108-11 (Stevens, J., dissenting).

53. Id. at 110 .

54. Id at 111 .

55. Id at 112 .

56. Id. at 113 . 
suffers from an omission or inadvertent error. As Judge Learned Hand explained, statutes are likely to be imprecise.

"All [legislators] have done is to write down certain words which they mean to apply generally to situations of that kind. To apply these literally may either pervert what was plainly their general meaning, or leave undisposed of what there is every reason to suppose they meant to provide for. Thus it is not enough for the judge just to use a dictionary. If he should do no more, he might come out with a result which every sensible man would recognize to be quite the opposite of what was really intended; which would contradict or leave unfulfilled its plain purpose." 57

In short, for Justice Stevens as for Judge Learned Hand, Congress is errorprone in its expression, and judges should presume that such error has occurred when the text and the background purpose do not fit comfortably together.

\section{Coal Miners}

In Barnhart v. Sigmon Coal Co., ${ }^{58}$ the Court enforced the clear but somewhat anomalous semantic import of the Coal Industry Retiree Health Benefit Act of 1992 (the "Coal Act"), ${ }^{59}$ a statute enacted to address the potential insolvency of coal industry retirement plans imposed by a series of collective bargaining agreements over many years. ${ }^{60}$ To ensure that the plans would be adequately funded, the Coal Act imposed contributions requirements on two classes of businesses. First, it imposed such obligations upon "signatory operators"-coal operators who had signed any of the previous pension agreements. ${ }^{61}$ Second, it required contributions from "related persons" - companies that had enjoyed statutorily specified forms of business affiliation with signatory operators. ${ }^{62}$ In Barnhart, the Commissioner of Social Security had imposed liability on the respondent coal company, which was neither a signatory operator nor a related person but was a successor in interest to a signatory operator (by virtue of having

57. Id. at 115 (footnote omitted) (quoting Learned Hand, How Far Is a Judge Free in Rendering a Decision?, in The Spirit of Liberty 103, 106 (I. Dilliard ed., 1952)).

58. 534 U.S. 438 (2002).

59. 26 U.S.C. $\$ \S 9701-9722(2000)$.

60. See Barnhart, 534 U.S. at 442-45.

61. 26 U.S.C. $\S 9701$ (c)(1).

62. Id. $\S 9701(\mathrm{c})(2)$. In particular, the statute provides that "a person shall be considered to be a related person to a signatory operator if that person" falls within one of following categories:

(i) a member of the controlled group of corporations (within the meaning of section 52(a)) which includes such signatory operator;

(ii) a trade or business which is under common control (as determined under section 52(b)) with such signatory operator; or

(iii) any other person who is identified as having a partnership interest or joint venture with a signatory operator in a business within the coal industry, but only if such business employed eligible beneficiaries, except that this clause shall not apply to a person whose only interest is as a limited partner. 
bought a signatory's mining assets). ${ }^{63}$ As relevant here, the Coal Act explicitly imposed liability on successors to "related persons" but included no such provision for imposing liability generally on successors to "signatory operators" themselves. ${ }^{64}$ Instead, the Act imposed tailored forms of liability upon successors to two very carefully drawn subclasses of signatory operators. ${ }^{65}$ Applying standard maxims of negative implication, ${ }^{66}$ the Court reasoned that " $[\mathrm{w}]$ here Congress wanted to provide successor liability in the ... Act, it did so explicitly."67

Justice Stevens again dissented. For him, Barnhart "raise[d] the question whether clear evidence of coherent congressional intent should inform the Court's construction of a statutory provision that seems, at first blush, to convey an incoherent message."68 For several reasons, his answer was that clear intent rather than apparent semantic import should govern here. First, he noted that the Court's reading of the statute precluded the Commissioner of Social Security, the official charged with administering the Act, from generally assigning liability to a signatory operator's successor in interest"the most logical recipient of liability, after the signatory itself."69 More dramatically, while relieving a direct successor of any such obligation, the Court's reading imposed such responsibility on a successor in interest of a signatory's corporate affiliate ("a related person") ${ }^{70}$ Thus, as Justice Stevens explained, if a signatory coal operator had been affiliated with a dairy (such that the dairy was a "related person"), and if each company then sold its assets to different buyers, the Act would assign financial responsibility for the signatory's retirees to the dairy's successor, but not to the signatory's successor. ${ }^{71}$ "If that result is not absurd," he observed, "it is surely incoherent. Why would Congress order such an odd result?"72

63. Barnhart, 534 U.S. at 448.

64. See 26 U.S.C. $\$ 9701$ (c)(2)(A) ("A related person shall also include a successor in interest of any person described in [the 'related persons' definition] in clause (i), (ii), or (iii).").

65. First, the Act explicitly provides for the liability of post-enactment succesors:

If a person becomes a successor of an assigned operator after the enactment date [of the Act], the assigned operator may transfer the assignment of an eligible beneficiary ... to such successor, and such successor shall be treated as the assigned operator with respect to such eligible beneficiary for purposes of this chapter.

Id. $\S 9706$ (b)(2). Second, another provision specifies the obligations of Individual Employer Plans under the 1978 or any subsequent agreement. For purposes of that provision, the Act specifies that " $[t]$ he term 'last signatory operator' shall include a successor in interest of such operator." Id. $\S 9711(\mathrm{~g})(1)$.

66. See supra text accompanying note 46.

67. Barnhart, 534 U.S. at $452-53$.

68. Id. at 462 (Stevens, J., dissenting).

69. Id. at 465 .

70. Id.

71. $I d$.

72. $I d$. 
Second, two of the bill's Senate sponsors made floor statements further suggesting that "Congress did not intend this result." unmistakably stated to his colleagues that "signatory operators" would include successors in interest. ${ }^{74}$ For Justice Stevens, this fact dovetailed importantly with his commonsense evaluation of the legislation itself:

If we assume that [the two sponsors] correctly understood their work product, the provision is coherent. For it is obviously sensible to impose the cost of health care benefits on successors to signatory operators, and equally obvious that there is far less justification for imposing such liability on successors to related companies that are not engaged in coal mining. ${ }^{75}$

For the Court to disregard the sponsors' statements, moreover, was "disrespectful, not only to those Senators, but to the entire Senate as well. For ... it apparently assumes that the Senators were either dissembling or unable to understand the meaning of the bill that they were sponsoring." $" 76$ Since no Senator rose to the floor to dispute the sponsors' account, Justice Stevens found it quite unlikely that they "misdescribed the coverage of the Act." 77

Third, imposing liability on successors would bring the Act's interpretation into harmony with the interpretation "consistently endorsed by the several Commissioners responsible for the administration of the Act" and with "the Court's treatment of successorship issues in other labor cases."78 And by assigning retired miners to a signatory's successors, the dissent's reading would help to avoid replicating the problems of unassigned retirees that inspired the Act's enactment in the first place. ${ }^{79}$

Although Justice Stevens admirably attempted to find a textual home for his position in the Dictionary Act's default rule that the term "corporations" includes successors in interest, ${ }^{80}$ it is clear that his result did not (and could

73. Id.

74. See id. at 466 (footnote omitted). As Justice Stevens's dissent highlights, the sponsors' statements were quite explicit:

Senator Rockefeller of West Virginia, who spoke "as the original author of this legislation," 138 Cong. Rec. 34034 (1992), unambiguously stated that the term "signatory operator" includes "a successor in interest of such operator." Id. at 34033. And in a written explanation of the measure that he placed in the Congressional Record, Senator Malcolm Wallop stated that the definition of the term "related person" was "intentionally very broad" and encompassed "successors to the collective bargaining agreement obligations of a signatory Id. operator."

75. Id. at 467 .

76. Id. at 469 .

77. $I d$.

78. Id. at $470-71$.

79. Id. at $471-72$.

80. His textual claim was as follows:

The Coal Act defines a "signatory operator" as "a person which is or was a signatory to a coal wage agreement." 26 U.S.C. \$ 9701(c)(1) (1994 ed.). The term "person" is not defined, but according to the Dictionary Act it includes 
not) depend on that conclusion. ${ }^{81}$ In particular, Justice Stevens closed his dissent with the following observation, which further illuminates his general approach to statutes:

In my judgment the holding in this case is the product of a misguided approach to issues of statutory construction. The text of the statute provides us with evidence that is usually sufficient to disclose the intent of the enacting Congress, but that is not always the case. There are occasions when an exclusive focus on text seems to convey an incoherent message, but other reliable evidence clarifies the statute and avoids the apparent incoherence. In such a case ... we should never permit a narrow focus on text to obscure a commonsense appraisal of that additional evidence. ${ }^{82}$

\section{Summary}

Three features emerge from Justice Stevens's decisions, of which the foregoing dissents are fairly representative. First, he believes that when the semantic import of a statutory text collides with persuasive evidence of a contrary legislative purpose or intent, the latter must prevail. ${ }^{83}$ Congress

"corporations, companies, associations, firms, partnerships, societies, and joint stock companies, as well as individuals." 1 U.S.C. $\S 1$. And, we know from 1 U.S.C. $\S 5$ that " $[t]$ he word 'company' or 'association', when used in reference to a corporation, shall be deemed to embrace the words 'successors and assigns of such company or association', in like manner as if these last-named words, or words of similar import, were expressed." Therefore, reading the term "signatory operator" to encompass direct successors is compatible with the default rules that Congress provided for interpreting its statutes.

Id. at 469-70.

81. Even if the Dictionary Act provides a generic default rule for understanding the term "company" or "corporation," the specific text of the Coal Act requires a different result. In particular, there is no way to make textual sense of the Coal Act's many specific provisions prescribing carefully tailored liability for successors of signatories or their related persons under the Act if successors of signatories were covered under the more general default rule prescribed by the Dictionary Act. See, e.g., Gozlon-Peretz v. United States, 498 U.S. 395, 407 (1991) ("A specific provision controls one of more general application."); Radzanower v. Touche Ross \& Co., 426 U.S. 148, 153 (1976) ("'Where there is no clear intention otherwise, a specific statute will not be controlled or nullified by a general one, regardless of the priority of enactment." (quoting Morton v. Mancari, 417 U.S. 535, 550-51 (1974))).

82. Barnhart, 534 U.S. at 472 (Stevens, J., dissenting).

83. See, e.g., Koons Buick Pontiac GMC, Inc. v. Nigh, 543 U.S. 50, 65 (2004) (Stevens, J., concurring) ("In recent years the Court has suggested that we should only look at legislative history for the purpose of resolving textual ambiguities or to avoid absurdities. It would be wiser to acknowledge that it is always appropriate to consider all available evidence of Congress' true intent when interpreting its work product."); United States v. Wells, 519 U.S. 482, 511 (1997) (Stevens, J., dissenting) (noting with approval that "the Court has routinely rejected literal statutory interpretations that would lead to anomalous results"). In Chapman v. United States, 500 U.S. 453, 476-77 (1991) (Stevens, J., dissenting), Justice Stevens approvingly quoted several cases that nicely capture his approach:

In construing a statute, Learned Hand wisely counseled us to look first to the words of the statute, but "not to make a fortress out of the dictionary; but to remember that statutes always have some purpose or object to accomplish, whose 
does not always state its intentions precisely, and a faithful agent must be on watch for evidence of legislative inadvertence. Second, in determining when Congress has misspoken, the Court should ascribe a rather robust presumption of reasonableness and coherence in legislative outcomes. In that sense, he falls within the Legal Process tradition of Henry M. Hart, Jr., and Albert M. Sacks, who urged courts to assume that legislation is the product of "reasonable persons pursuing reasonable purposes reasonably." 84 To Justice Stevens, it did not make sense to have an obvious calendar-year-

sympathetic and imaginative discovery is the surest guide to their meaning." Cabell v. Markham, 148 F. 2d 737, 739 (CA2), aff'd, 326 U.S. 404 (1945). In the past, we have recognized that "frequently words of general meaning are used in a statute, words broad enough to include an act in question, and yet a consideration of ... the absurd results which follow from giving such broad meaning to the words, makes it unreasonable to believe that the legislator intended to include the particular act." Church of Holy Trinity v. United States, 143 U.S. 457, 459 (1892). These words guided our construction of the statute at issue in Public Citizen v. Department of Justice, 491 U.S. 440, 454 (1989), when we also noted that "[l]ooking beyond the naked text for guidance is perfectly proper when the result it apparently decrees is difficult to fathom or where it seems inconsistent with Congress' intention ...."

Id. Similarly, in Conroy v. Aniskoff, 507 U.S. 511, 518 n.12 (1993) (Stevens, J.), Justice Stevens wrote as follows:

A jurisprudence that confines a court's inquiry to the "law as it is passed," and is wholly unconcerned about "the intentions of legislators," would enforce an unambiguous statutory text even when it produces manifestly unintended and profoundly unwise consequences. Respondents have argued that this is such a case. We disagree. Justice Scalia, however, is apparently willing to assume that this is such a case, but would nevertheless conclude that we have a duty to enforce the statute as written even if fully convinced that every Member of the enacting Congress, as well as the President who signed the Act, intended a different result. Again, we disagree.

Id. (citations omitted).

84. Henry M. Hart, Jr. \& Albert M. Sacks, The Legal Process 1378 (William N. Eskridge, Jr. \& Philip P. Frickey eds., 1994) (1958). For discussion of the post-war influence of these materials, see, for example, T. Alexander Aleinikoff, Updating Statutory Interpretation, 87 Mich. L. Rev. 20, 26-27 (1988) (discussing the impact of the Hart and Sacks materials), and William N. Eskridge, Jr. \& Philip P. Frickey, Legislation Scholarship and Pedagogy in the Post-Legal Process Era, 48 U. Pitt. L. Rev. 691, 698-99 (1987) (same). Along these lines, it is surely also plausible to think of Justice Stevens's presumption of coherence as a normatively rooted presumption about how judges should read the legislative process, rather than a descriptive account of how the process actually works. Certainly, others have suggested that such an account explains Legal Process purposivism, which mirrors Justice Stevens's own approach. See, e.g., Daniel A. Farber \& Philip P. Frickey, Foreword: Positive Political Theory in the Nineties, 80 Geo. L.J. 457, 475 (1992) (noting "the possibility that Hart and Sacks were not so much panglossian empiricists as savvy normativists - crafters of assumptions that provide useful judicial and administrative sideconstraints upon the less attractive features of politics"); Peter L. Strauss, The Common Law and Statutes, 70 U. Colo. L. Rev. 225, 242 (1999) (suggesting that the Legal Process approach reflects a "normative statement prescribing proper attitudes for judges in their dealing with the work of legislatures, rather than a positive one describing what legislatures are"). Even if one understands Justice Stevens's presumption of coherence in that light, I argue below that a competing normative presumption-that legislation typically reflects untidy compromise-makes more sense of the constitutional structure than does the Legal Process presumption of reasonable coherence. See infra Part III.A-B. 
end filing requirement that expired before the close of business on December 31; it did not make sense to provide for attorney's fees but deny the use of experts who could provide lower-cost substitutes for attorney services; it did not make sense to assign mine industry retirees to successors of non-coal companies that had been affiliated with signatory coal operators, but not to the successors of the signatories themselves. Underlying each dissent is a strong sense that federal courts should act as though Congress behaves coherently, even when the semantic detail suggests otherwise. ${ }^{85}$ Third, in determining legislative intent, he finds it appropriate if not necessary to consult a statute's internal legislative history-particularly the authoritative statements of the committees and sponsors responsible for framing bills. ${ }^{86}$ For Justice Stevens, statutory

85. One further example illustrates this phenomenon with particular clarity. In United States v. Wells, 519 U.S. 482, 486 (1997), the Court construed 18 U.S.C. § 1014 (1994), which criminalizes knowingly making any "false statement or report" to a bank for the purpose of securing a loan. At issue was whether the statute contained a materiality requirement. The Court found that because the false statement statute contained no express materiality requirement, "the natural reading" did not include such an element. Wells, 519 U.S. at 492 . More important, the Court noted that when Congress enacted $\S 1014$ as part of the 1948 recodification of the Criminal Code, "it explicitly included materiality in other provisions." Id. Indeed, $\$ 1014$ itself was a composite of more than a dozen previous provisions, most but not all of which had lacked a materiality requirement prior to the recodification. See id. In consolidating those provisions that were to become $\S 1014$, Congress dropped the materiality requirement from all of them, leading the Court to infer that Congress had done so "deliberately." Id. at 493. The Court thus used the classic process of negative implication to draw inferences from the disparate inclusion and omission of a materiality requirement in various statutory provisions. For Justice Stevens, disparate inclusion and omission of an express materiality requirement is not evidence of deliberate contrast but rather of unintended legislative deviation from an otherwise coherent background policy. Surveying the entire body of federal criminal statutes, Justice Stevens wrote as follows:

[A]t least 100 federal false statement statutes may be found in the United States Code. About 42 of them contain an express materiality requirement; approximately 54 do not. The kinds of false statements found in the first category are, to my eyes at least, indistinguishable from those in the second category. Nor is there any obvious distinction between the range of punishments authorized by the two different groups of statutes. ... It seems farfetched that Congress made a deliberate decision to include or to omit a materiality requirement every time it created a false statement offense. Far more likely, in my view, Congress simply assumed ... that the materiality requirement would be implied wherever it was not explicit.

Id. at 505-09 (Stevens, J., dissenting).

86. Justice Stevens has suggested that in casting their votes, legislators justifiably rely on the views expressed by committees and sponsors:

Legislators, like other busy people, often depend on the judgment of trusted colleagues when discharging their official responsibilities. If a statute such as the Expedited Funds Availability Act has bipartisan support and has been carefully considered by committees familiar with the subject matter, Representatives and Senators may appropriately rely on the views of the committee members in casting their votes. In such circumstances, since most Members are content to endorse the views of the responsible committees, the intent of those involved in the drafting process is properly regarded as the intent of the entire Congress. 
interpretation is a holistic endeavor, guided by the premise that legislative policymaking tends to be reasonably coherent, that statutory drafting tends to be messy and imprecise, and that a true faithful agent properly corrects apparent infelicities in drafting to make a statute more coherent with its own apparent purposes and with relevant policies reflected in other laws.

Certainly, that approach had become orthodox well before Justice Stevens took his seat on the Court three decades ago-and remained so for some time thereafter. ${ }^{87}$ Starting from the inception of the Rehnquist Court nearly two decades ago, however, the Court has moved noticeably although not single-mindedly in a different direction. Rather than deviating from the clear semantic import of the enacted text, the Court's more recent decisions have tended instead to emphasize that the legislative process is opaque and path dependent, that virtually all laws entail compromise, and that compromises are frequently messy rather than coherent. So it takes the text as it finds it rather than imposing purpose-driven coherence on a messy text. Because the Court's "new textualism" 88 represents the most serious postwar challenge to the tradition of purposivism practiced by Justice Stevens, no examination of his interpretive approach would be complete without also considering that counter-tradition.

Bank One Chi., N.A. v. Midwest Bank \& Trust Co., 516 U.S. 264, 276-77 (1996) (Stevens, J., concurring). In City of Chicago v. Environmental Defense Fund, 511 U.S. 328, 345 n.7 (1994) (Stevens, J., dissenting), moreover, Justice Stevens advanced a similar justification:

The purpose of a committee report is to provide the Members of Congress who have not taken part in the committee's deliberations with a summary of the provisions of the bill and the reasons for the committee's recommendation that the bill should become law. The report obviously does not have the force of law. Yet when the text of a bill is not changed after it leaves the committee, the Members Id. are entitled to assume that the report fairly summarizes the proposed legislation.

87. See, e.g., Pub. Citizen v. United States Dep't of Justice, 491 U.S. 440, 452-53 (1989) (concluding that an acquaintance with the Federal Advisory Committee Act's "purposes, as manifested by its legislative history and as recited in ... the Act, reveals that it cannot have been Congress' intention" to adopt the conventional import of the word "utilize"); CIR v. Brown, 380 U.S. 563, 571 (1965) ("Unquestionably the courts, in interpreting a statute, have some scope for adopting a restricted rather than a literal or usual meaning of its words where acceptance of that meaning would lead to absurd results ... or would thwart the obvious purpose of the statute." (internal quotation omitted)); Int'l Longshoremen's \& Warehousemen's Union v. Juneau Spruce Corp., 342 U.S. 237, 243 (1952) ("That reading of the Act does not, to be sure, take the words . . . in their historic, technical sense. But literalness is no sure touchstone of legislative purpose. The purpose here is more closely approximated, we believe, by giving the historic phrase a looser, more liberal meaning in the special context of this legislation."); United States v. Carbone, 327 U.S. 633, 637 (1946) (" $[\mathrm{N}]$ ot every person or act falling within the literal sweep of the ... Act necessarily comes within its intent and purpose. That language must be read and applied in light of the evils which gave rise to the statute and the aims which the proponents sought to achieve."). This interpretive tradition, of course, also underpinned the Court's highly influential Holy Trinity decision. See supra text accompanying notes 7-17.

88. The terminology is attributed to William N. Eskridge, Jr., The New Textualism, 37 UCLA L. Rev. 621 (1990). 


\section{The Presumption of Deliberate Drafting AND MeSSy COMPROMISE}

Because I have extensively discussed the premises of modern textualism in previous writings, I will sketch the textualist position in brief here. The central premise of modern textualism is that the Court must enforce the statute as written rather than trying to adjust it to reflect a background purpose drawn from the overall tenor of the statute, its title, or, perhaps especially, its legislative history. This approach rests on an apparent presumption that legislators choose the words of a statute for a reason and that a complex and opaque legislative process can be expected to produce rough-hewn compromises that do not necessarily capture a fully coherent set of policy goals. To oversimplify a bit, when the semantic meaning of a statute is clear, for textualists that is the end of the matter. ${ }^{89}$

The formal basis for this position has perhaps been most clearly expressed by the Court's leading textualist, Justice Scalia, who emphasizes that "[w]e are governed by laws, not by the intentions of legislators.... 'The law as it passed is the will of the majority of both houses, and the only mode in which that will is spoken is in the act itself." 90 In other words, because Article I, Section 7, of the Constitution prescribes a specific and rather elaborate method of enacting laws-bicameralism and presentment-

89. The statement in text is an oversimplification for two reasons: First, the Court's textualists subscribe to some version of the notion that the federal courts may depart from the clear import of the enacted text to avoid an absurd result. See, e.g., City of Columbus v. Ours Garage \& Wrecking Serv., Inc., 536 U.S. 424, 449 n.4 (2002) (Scalia, J., dissenting) ("A possibility so startling (and unlikely to occur) is well enough precluded by the rule that a statute should not be interpreted to produce absurd results."); INS v. Cardoza-Fonseca, 480 U.S. 421, 452 (1987) (Scalia, J., concurring in the judgment) (noting that courts may properly depart from the plain meaning of a statute in order to avoid a "patent absurdity"). I have criticized that position rather extensively in a prior article. See John F. Manning, The Absurdity Doctrine, 116 Harv. L. Rev. 2387 (2003). Second, textualists sometimes invoke so-called "clear statement rules"-constitutionally inspired (but not required) canons of construction that push interpreters away from interpretations that risk intrusion upon constitutional values such as federalism. See, e.g., United States v. Nordic Vill., Inc., 503 U.S. 30, 33-34 (1992) (Scalia, J.) (requiring clear statement of legislative intent to waive federal sovereign immunity); Kaiser Aluminum \& Chem. Corp. v. Bonjorno, 494 U.S. 827, 841 (1990) (Scalia, J., concurring) (presuming that statutes apply prospectively absent a clear indication to the contrary); Dellmuth v. Muth, 491 U.S. 223, 233 (1989) (Scalia, J., concurring) (stressing that Congress may eliminate sovereign immunity under Section 5 of the Fourteenth Amendment if the statutory text "clearly subjects" the state to suit for damages). Although the legitimacy of such canons is beyond the scope of this Essay, I note that a growing body of scholarship criticizing the canon of constitutional avoidance tends to raise basic questions about the consistency of clear statement rules with the premises of textualism. See, e.g., Jerry L. Mashaw, Greed, Chaos, and Governance 102-05 (1997) (relying on game theory to demonstrate the distorting effect of clear statement rules such as the canon of avoidance); Frederick Schauer, Ashwander Revisited, 1995 Sup. Ct. Rev. 71, 74 (noting that "it is by no means clear that a strained interpretation of a federal statute that avoids a constitutional question is any less a judicial intrusion than the judicial invalidation on constitutional grounds of a less strained interpretation of the same statute").

90. Conroy v. Aniskoff, 507 U.S. 511, 519 (1993) (Scalia, J., concurring in the judgment) (quoting Aldridge v. Williams, 44 U.S. (3 How.) 9, 24 (1845)). 
the language that emerges from that process has a singular claim to legitimate authority, at least when the resulting text is clear. As Justice Scalia has put it, the enacted text always trumps "unenacted legislative intent."91

91. Cardoza-Fonseca, 480 U.S. at 453 (Scalia, J., concurring in the judgment). In a recent article, I argued that textualists speak with some (ultimately harmless) imprecision when they cast their approach as one that favors the enacted text over unenacted extratextual materials. See John F. Manning, What Divides Textualists from Purposivists, 106 Colum. L. Rev. 71 (2006). Because modern textualists recognize that the meaning of all texts depends on context, the more accurate account of their position is that interpreters should resolve latent ambiguities in text by first examining semantic context-evidence of the way a reasonable person would use the enacted words in context. Id. at 92-94. When such evidence yields a clear answer to an interpretive question, textualists would generally give it precedence over policy context-evidence about the way a reasonable person would address the mischief at which the statute is directed. See id. at 92-93. Ultimately, the proposed change in emphasis may itself be a mere matter of semantics. See id. at 77, 95. For whether one frames the question as text versus purpose or semantic versus policy context, the basic justification for textualism remains intact: Even if textualists ultimately choose between competing elements context, their approach finds ample justification in the fact that respect for a statute's clearly expressed semantic detail affords legislators the only reliable means to strike predictable compromises in the legislative process. See id. at 103-05. If legislators with the power to insist upon a compromise wish to strike a bargain about the contours to the policy they find acceptable, they must be able to agree upon words that will reliably frame that policy at an appropriate level of generality. See infra Part III.A.

In a characteristically thoughtful essay appearing in this Symposium, Professor Abner Greene suggests that the distinction between semantic meaning and background purpose is less meaningful than textualists claim. See Abner S. Greene, The Missing Step of Textualism, 74 Fordham L. Rev. 1913, 1916-22 (2006). In particular, he argues that because textualists acknowledge that statutes have meaning only in context, they are able to rely on assertions about contextual nuance to sneak purposive analysis into their assessment of word meaning. See id. Although full consideration of his provocative contention is beyond this Essay's scope, I believe that Professor Greene's analysis underestimates the extent to which textualists give priority to semantic elements of context (evidence about the way speakers use language), even when it contradicts the policy elements of context (evidence about the way speakers would solve problems addressed by the language). See Manning, supra, at 9296. Faithfully applied, this ordering of priority continues to differentiate textualism from traditional methods of purposivism. See Manning, supra note 89, at 2462-64 (explaining the constraints produced by an emphasis on conventional semantic usage).

Along these lines, it is worth pausing to clarify a point made in my earlier work. In response to my prior writing, see Manning, supra note 4, at $111 \mathrm{n} .434$, Professor Greene invokes a hypothetical asking how a subordinate should interpret a hotel manager's directive to "gather all the ashtrays in the public areas of the hotel." See Greene, supra, at 1921; see also Gerald C. MacCallum, Jr., Legislative Intent, 75 Yale L.J. 754, 771-72 (1966) (proposing that example); William N. Eskridge, Jr., Textualism: The Unknown Ideal?, 96 Mich. L. Rev. 1509, 1549 (1997) (book review) (elaborating upon the ashtray hypothetical). In particular, as Professor Greene notes, I had suggested that a textualist would disfavor ripping out ashtrays that were bolted to the walls because "no reasonable user of language would use or understand the phrase 'gather all ashtrays from the public spaces,' in context, to mean movable and nonmovable ashtrays." Manning, supra note 4, at $111 \mathrm{n} .434$. Professor Greene argues that my conclusion demonstrates the thinness of the textualists' distinction between semantic and policy considerations. As I clarified in later writing, however, the ashtray hypothetical, properly understood, is ultimately inapposite to the appropriate method of statutory interpretation. See Manning supra note 89, at 2462-63 n.274. That hypothetical of course builds on Grice's proposition that when speakers violate the "cooperative principle" of conversation, a listener is sometimes justified in assigning an unconventional meaning to the speaker's utterance. See supra note 25 (discussing Grice). In 
Behind this formal theory of the constitutional structure lies a theory of the way the political process works. In the judicial opinions of Justice Scalia, two major premises about the legislative process predominate. First, virtually all laws reflect some form of compromise, and compromises tend to be awkward precisely because they typically split the difference between competing positions. ${ }^{92}$ This premise, if sustainable, makes it quite difficult to presume, as purposivists do, that a statute's seemingly over- or underinclusive rules have "inadvertently" fallen short of some overarching background purpose. As Justice Scalia has written, "[t]he final form of a statute ... is often the result of compromise among various interest groups, resulting in a decision to go so far and no farther."93 If so, then "[d]eduction from the 'broad purpose' of a statute begs the question if it is used to decide by what means (and hence to what length) Congress pursued that purpose; to get the right answer to that question there is no substitute for the hard job... of reading the whole text." 94 Or as the Court's other leading textualist, Justice Clarence Thomas, made clear in the previously discussed Barnhart case, where compromise is present, the contours of a statute may reflect the imperatives of the political process rather than a logical ordering of legislative policy:

[N]egotiations surrounding enactment of this bill tell a typical story of legislative battle among interest groups, Congress, and the President .... As such, a change in any individual provision could have unraveled the whole. It is quite possible that a [different] bill . . . would not have survived the legislative process. The deals brokered during a Committee markup, on the floor of the two Houses, during a joint House and Senate Conference, or in negotiations with the President, however, are not for us to judge or second-guess. ${ }^{95}$

To preserve a potential compromise, the Court's textualists deem it necessary to hew closely to the semantic meaning of the only text that has cleared Article I's requirements of bicameralism and presentment, as well as the many complex legislative rules that supplement that process. ${ }^{96}$

view of Grice's "maxim of quality," the listener might infer that the request to collect "all the ashtrays" rested on a false factual assumption that "all" the relevant ashtrays were loose and thus easy to retrieve. See Manning, supra note 89, at 2462 n.274. Grice's assumptions about such seemingly awkward utterances, however, do not translate well from the context of individual communication to that of legislation. See id. at 2462-63 n.274. Because the final content of a statutory text may reflect a bargaining process that splits the difference between sharply conflicting views or papers over deeply felt disagreements, it is unrealistic to equate the awkwardness of a statute with the kind of linguistic inadvertence that a listener might reasonably ascribe to an individual in a cooperative conversational setting. See id.

92. See Courtney Simmons, Unmasking the Rhetoric of Purpose: The Supreme Court and Legislative Compromise, 44 Emory L.J. 117, 126 (1995).

93. E. Assocs. Coal Corp. v. United Mine Workers, 531 U.S. 57, 68-69 (2000) (Scalia, $\mathrm{J}$., concurring in the judgment).

94. Babbitt v. Sweet Home Chapter of Cmtys. for a Great Or., 515 U.S. 687, 726 (1995) (Scalia, J., dissenting).

95. Barnhart v. Sigmon Coal Co., Inc., 534 U.S. 438, 461 (2002).

96. See infra Part III.A. 
Second, textualists tend to believe that the post-New Deal Court's most common source for identifying purpose-a bill's legislative history-does not reliably reflect Congress's desires and is otherwise of dubious constitutional legitimacy. Again, Justice Scalia has taken the lead. For him, the use of legislative history presents a Catch-22 for the purposivist. Either it is invoked because it is mere evidence of how Congress understood the words it enacted, in which case legislative history is typically an unreliable barometer. ${ }^{97}$ Or if (as Justice Stevens has suggested) rank-and-file legislators accept the statements of committees or sponsors as authoritative expressions of the majority's position, then the concern shifts from one of evidentiary unreliability to one of constitutional dimension:
[A]ssuming [that] .
[Congress] desire[s] to leave details to the committees, the very first provision of the Constitution forbids it. Article I, \& 1, provides that "[a]ll legislative Powers herein granted shall be vested in a Congress of the United States, which shall consist of a Senate and House of Representatives." It has always been assumed that these powers are nondelegable- - or, as John Locke put it, that legislative power consists of the power "to make laws, ... not to make legislators." J. Locke, Second Treatise of Government 87 (R. Cox ed. 1982). No one would think that the House of Representatives could operate in such fashion that only the broad outlines of bills would be adopted by vote of the full House, leaving minor details to be written, adopted, and voted upon only by the cognizant committees. Thus, if legislation consists of forming an "intent" rather than adopting a text (a proposition with which I do not agree), Congress cannot leave the formation of that intent to a small band of its number, but must, as the Constitution says, form an intent of the Congress. ${ }^{98}$

For Justice Scalia, then, either legislative history supplies faulty evidence of congressional intent or is unconstitutionally treated by courts as if it does.

Much the way Justice Stevens's purposivism is captured by the academic and judicial writings of Judge Posner, Justice Scalia's textualism finds thoughtful corroboration in the work of Posner's colleague on the University of Chicago law faculty and the Seventh Circuit, Judge

97. Even with what the Court long regarded as the most authoritative evidence of legislative intent-the reports of the responsible legislative committees-Justice Scalia has thought it "most unlikely that many Members of either Chamber [have] read the pertinent portions of the Committee Reports before voting on the bill-assuming ... that the Reports were available before the vote." Wis. Pub. Intervenor v. Mortier, 501 U.S. 597, 620 (1991) (Scalia, J., concurring in the judgment); see also, e.g., W. Va. Univ. Hosps. v. Casey, 499 U.S. 83, 98-99 (1991) (Scalia, J.) ("Where [the statute] contains a phrase that is unambiguous-that has a clearly accepted meaning in both legislative and judicial practice-we do not permit it to be expanded or contracted by the statements [of purpose] of individual legislators or committees during the course of the enactment process."); Blanchard v. Bergeron, 489 U.S. 87, 98 (1989) (Scalia, J., concurring in part and concurring in the judgment) ("I am confident that only a small proportion of the Members of Congress read either one of the Committee Reports in question, even if (as is not always the case) the Reports happened to have been published before the vote ....").

98. Bank One Chi., N.A. v. Midwest Bank \& Trust Co., 516 U.S. 264, 280 (1996) (Scalia, J., concurring in part and concurring in the judgment). 
Easterbrook. ${ }^{99}$ Building on Arrovian game theory, ${ }^{100}$ Judge Easterbrook emphasizes that the legislative process is opaque, path-dependent, and highly complex: "Although legislators have individual lists of desires, priorities, and preferences, it turns out to be difficult, sometimes impossible, to aggregate these lists into a coherent collective choice. Every system of voting has flaws. The one used by legislatures is particularly dependent on the order in which decisions are made."101 In other words, the precise contours of legislative policy may reflect the procedural sequence of legislative events rather than a frictionless implementation of coherent policy impulses. And because of the deep complexities of the legislative process, it may be difficult for judges after the fact to retrace the steps of legislative process to determine what procedural influences helped shape the legislation. Bills must "run the gamut of the process," which involves "committees, fighting for time on the floor, compromise because other members want some unrelated objective, passage, exposure to veto, and so on."102 When one adds strategic behavior such as logrolling to the mix, moreover, "the legislative process is submerged and courts lose the information they need to divine the body's design."103 Given these complexities, Easterbrook thinks it "impossible for a court-even one that knows each legislators' complete table of preferences-to say what the whole body would have done with a proposal it did not consider in fact." 104 If correct, this conclusion in turn casts doubt on the purposivist idea that courts can ascertain with meaningful accuracy what Congress would have done had it expressly confronted an apparent mismatch between a clear statutory text and the background purpose that inspired it.

Second, Judge Easterbrook makes the related-and, for present purposes, highly significant-points that most law requires compromise, that compromise goes so far and no farther in pursuit of legislative purposes, and that abstracting from textually embedded rules to background purposes may in fact disturb a legislative choice to specify limits on a desired statutory policy in order to secure a needed compromise. Because 19.

99. The discussion in this paragraph builds on Manning, supra note 89 , at 2387,2408 -

100. See, e.g., Kenneth J. Arrow, Social Choice and Individual Values (Yale Univ. Press, 2d ed. 1963) (1951).

101. See Frank H. Easterbrook, Statutes' Domains, 50 U. Chi. L. Rev. 533, 547-48 (1983).

102. Frank H. Easterbrook, The Role of Original Intent in Statutory Construction, 11 Harv. J.L. \& Pub. Pol'y 59, 64 (1988).

103. Easterbrook, supra note 101 , at 548 .

104. Id. at 547-48. Where such premises hold, it may be impossible to identify what the legislature collectively regards as the "'best' alternative," and "the final outcome may be arbitrary (for example, a function of group fatigue) or determined by specific institutional features of decisionmaking (for example, rules governing the order of voting on motions)." Kenneth A. Shepsle, Congress Is a "They," Not an "It": Legislative Intent as Oxymoron, 12 Int'l Rev. L. \& Econ. 239, $241-42$ (1992). For an excellent and largely critical appraisal of the way Arrow's Theorem is invoked in the interpretation debate, see Daniel A. Farber \& Philip P. Frickey, Law and Public Choice: A Critical Introduction 47-55 (1991). 
"[l]egislation reflects compromise among competing interests," Judge Easterbrook argues that "[i]t upsets the legislative balance to push the outcome farther in either direction."105 Or put another way, "law is like a vector. It has length as well as direction. We must find both, or we know nothing of value. To find length we must take account of objectives, of means chosen, and of stopping places identified."106 From this starting point, Judge Easterbrook maintains that purposivism disregards the role of compromise in the legislative process by transforming all rules (with more or less definite stopping points) into standards (with more or less openended goals):

A legislature that seeks to achieve Goal $\mathrm{X}$ can do so in one of two ways. First, it can identify the goal and instruct courts or agencies to design rules to achieve the goal. In that event, the subsequent selection of rules implements the actual legislative decision, even if the rules are not what the legislature would have selected itself. The second approach is for the legislature to pick the rules. It pursues Goal X by Rule $Y$. The selection of $Y$ is a measure of what Goal $X$ was worth to the legislature, of how best to achieve $X$, and of where to stop in pursuit of $X$. Like any other rule, $Y$ is bound to be imprecise, to be over- and under-inclusive. This is not a good reason for a court, observing the inevitable imprecision, to add to or subtract from Rule $\mathrm{Y}$ on the argument that, by doing so, it can get more of Goal X. The judicial selection of means to pursue $X$ displaces and directly overrides the legislative selection of ways to obtain $X$. It denies to legislatures the choice of creating or withholding gapfilling authority. ${ }^{107}$

105. Heath v. Varity Corp., 71 F.3d 256, 258 (7th Cir. 1995) (Easterbrook, J.); see also, e.g., Hrubec v. Nat'l R.R. Passenger Corp., 49 F.3d 1269, 1270 (7th Cir. 1995) (Easterbrook, J.) ("Many laws are compromises, going thus far and no further in pursuit of a goal."); Frank H. Easterbrook, Foreword: The Supreme Court, 1983 Term-The Court and the Economic System, 98 Harv. L. Rev. 4, 46 (1984) [hereinafter Easterbrook, Foreword] ("If legislation grows out of compromises among special interests, . . . a court cannot add enforcement to get more of what Congress wanted .... When a court observes that Congress propelled Group $\mathrm{X}$ part way to its desired end, it cannot assist Group $\mathrm{X}$ farther along the journey without undoing the structure of the deal."). I should note that Judge Easterbrook's theory of legislation sometimes tends to emphasize the premises of interest group theory, which suggests that legislation reflects private deals among competing interest groups. See, e.g., Frank H. Easterbrook, The State of Madison's Vision of the State: A Public Choice Perspective, 107 Harv. L. Rev. 1328, 1346-47 (1994) (arguing that "when faction dominates the creation of laws," such laws merely "reflect the outcome of a bargaining process among factions (and their representatives)"). It should be noted that one can expect compromise even in legislation that is not dominated by well-organized interest groups. As Jeremy Waldron has thus written, legislation is "the product of a multi-member assembly, comprising a large number of persons of quite radically differing aims, interests, and backgrounds." Jeremy Waldron, Law and Disagreement 125 (1999). Accordingly, any statute's "specific provisions" might be "the result of compromise and line-item voting." Id.

106. Easterbrook, supra note 102, at 63; see also, e.g., Contract Courier Servs. v. Res. \& Special Programs Admin., U.S. Dep't of Transp., 924 F.2d 112, 115 (7th Cir. 1991) (Easterbrook, J.) ("Statutes do more than point in a direction, such as 'more safety'. They achieve a particular amount of that objective, at a particular cost in other interests.").

107. Easterbrook, supra note 101 , at 546-47. 
Accordingly, when purposivists rely on "an imputed 'spirit' to convert one approach into another," such an approach "dishonors the legislative choice as effectively as expressly refusing to follow the law." 108

I have considered the merits and demerits of these process assumptions at length in earlier writing, and I will add but a few words below about competing purposivist and textualist theories of the legislative process. For present, it suffices to note that the Rehnquist Court tended to embrace important elements of the foregoing textualist critique of purposivism. ${ }^{109}$ In particular, that Court seemed firmly to embrace the idea that legislation entails often unknowable and messy compromise, and that federal courts in a system premised on legislative supremacy should respect the rules clearly articulated in the statutory text, even if they produce awkward results at odds with the statute's apparent purpose. In particular, the Court now starts from the premise that "[s]tatutes are seldom crafted to pursue a single goal, and [that] compromises necessary to their enactment may require adopting means other than those that would most effectively pursue the main goal."110 Accordingly, the Court no longer finds it appropriate to use a statute's "overarching legislative purpose" to smooth over the inevitable rough spots in a statutory text.11 And while recognizing that dissatisfaction with a statute's final shape "is often the cost of legislative compromise," the Court has made plain that " $[t]$ he deals brokered during a Committee markup, on the floor of the two Houses, during a joint House and Senate Conference, or in negotiations with the President ... are not for [the courts] to judge or second-guess."112 Judges, in other words, "are bound, not only by the ultimate purposes Congress has selected, but by the means it has deemed appropriate, and prescribed, for the pursuit of those purposes."113 To be sure, the Court in recent years has issued the occasional opinion that reflects classic purposivism of the sort practiced by

108. Frank H. Easterbrook, Text, History, and Structure in Statutory Interpretation, 17 Harv. J.L. \& Pub. Pol'y 61, 68 (1994); see also, e.g., Walton v. United Consumers Club, Inc., 786 F.2d 303, 310 (7th Cir. 1986) (Easterbrook, J.) ("Courts should confine their attention to the purposes Congress sought to achieve by the words it used.").

109. Hints of the present approach had begun to emerge near the end of the Burger Court. In its final year, that Court thus unanimously explained that

Congress may be unanimous in its intent to stamp out some vague social or economic evil; however, because its Members may differ sharply on the means for effectuating that intent, the final language of the legislation may reflect hardfought compromises. Invocation of the "plain purpose" of legislation at the expense of the terms of the statute itself takes no account of the processes of compromise.

Bd. of Governors of the Fed. Reserve Sys. v. Dimension Fin. Corp., 474 U.S. 361, 374 (1986).

110. Landgraf v. USI Film Prods., 511 U.S. 244, 286 (1994). Indeed, perhaps surprisingly, the opinion for the Court in Landgraf was written by Justice Stevens himself.

111. Barnhart v. Sigmon Coal Co., 534 U.S. 438, 461 (2002).

112. Id.

113. MCI Telecomms. Corp. v Am. Tel. \& Tel. Co., 512 U.S. 218, 231 n.4 (1994). 
Justice Stevens. ${ }^{114}$ But textualist themes about legislative compromise and respecting the rules embedded in the text of statutes have become quite familiar in the Court's opinions, ${ }^{115}$ even at times in those authored by Justices who would surely not count themselves as textualists. ${ }^{116}$

114. See Michael C. Dorf, The Supreme Court, 1997 Term-Foreword: The Limits of Socratic Deliberation, 112 Harv. L. Rev. 4, 6-7 (1998) (arguing that the Court continues to have an eclectic approach to statutory interpretation). For recent examples of strongly purposivist reasoning, see Johnson v. United States, 529 U.S. 694, 706 n.9 (2000) (Souter, J.) ("[I]n relying on an uncommon sense of the word, we are departing from the rule of construction that prefers ordinary meaning. But this is exactly what ought to happen when the ordinary meaning fails to fit the text and when the realization of clear congressional policy (here, favoring the ability to impose supervised release) is in tension with the result that customary interpretive rules would deliver." (citation omitted)); Clinton v. City of New York, 524 U.S. 417, 428-29 (1998) (broadening an expedited review provision because the literal meaning undermined the statutory purpose to provide "a prompt and authoritative judicial determination of the constitutionality of the Act"); Lewis v. United States, 523 U.S. 155,160 (1998) (refusing to enforce a statute's conventional meaning when "a literal reading of the words ... . would dramatically separate the statute from its intended purpose"). I should also note that the Court's approach to implied federal preemption of state law generally reflects premises more akin to those evident in its former purposivism. See Daniel J. Meltzer, The Supreme Court's Judicial Passivity, 2002 Sup. Ct. Rev. 343, 364-68 (arguing that contrary to its default approach to statutory interpretation, the Court engages in significant interpretive lawmaking in implied preemption cases).

115. See, e.g., Cooper Indus. v. Aviall Servs., 543 U.S. 157, 167 (2004) (Thomas, J.) ("Given the clear meaning of the text, there is no need to resolve this dispute or to consult the purpose of CERCLA at all."); Ragsdale v. Wolverine World Wide, Inc., 535 U.S. 81, 9394 (2002) (Kennedy, J.) ("Like any key term in an important piece of legislation, the [relevant] figure was the result of compromise between groups with marked but divergent interests in the contested provision. . . Courts and agencies must respect and give effect to these sorts of compromises."); Artuz v. Bennett, 531 U.S. 4, 10 (2000) (Scalia, J.) (refusing to consider various "policy arguments" while embracing what the Court viewed as "the only permissible interpretation of the text-which may, for all we know, have slighted policy concerns on one or the other side of the issue as part of the legislative compromise that enabled the law to be enacted"); Pa. Dep't of Corr. v. Yeskey, 524 U.S. 206, 212 (1998) (Scalia, J.) ("[A]ssuming . . . that Congress did not envisio[n] that the [Americans with Disabilities Act] would be applied to state prisoners, in the context of an unambiguous statutory text that is irrelevant." (second alteration in original) (citation and internal quotation omitted)); Oncale v. Sundowner Offshore Servs., Inc., 523 U.S. 75, 79 (1998) (Scalia, J.) ("[S]tatutory prohibitions often go beyond the principal evil to cover reasonably comparable evils, and it is ultimately the provisions of our laws rather than the principal concerns of our legislators by which we are governed."); Brogan v. United States, 522 U.S. 398, 403 (1998) (Scalia, J.) (observing "the reality that the reach of a statute often exceeds the precise evil to be eliminated" and explaining that "it is not, and cannot be, our practice to restrict the unqualified language of a statute to the particular evil that Congress was trying to remedy-even assuming that it is possible to identify that evil from something other than the text of the statute itself"); W. Va. Univ. Hosps., Inc. v. Casey, 499 U.S. 83, 98 (1991) (Scalia, J.) (noting that "the purpose of a statute includes not only what it sets out to change, but also what it resolves to leave alone," and that "[ $t]$ he best evidence of that purpose is the statutory text adopted by both Houses of Congress and submitted to the President" (citation omitted)).

116. See, e.g., Bates v. United States, 522 U.S. 23, 29 (1997) (Ginsburg, J.) ("The text of $\$ 1097$ (a) does not include an 'intent to defraud' state of mind requirement, and we ordinarily resist reading words or elements into a statute that do not appear on its face."); Nat'l Org. for Women, Inc. v. Scheidler, 510 U.S. 249, 262 (1994) (Rehnquist, C.J.) ("[T] he fact that [the Racketeer Influenced and Corrupt Organizations Act] has been applied in situations not expressly anticipated by Congress does not demonstrate ambiguity. It demonstrates 


\section{LESSONS FROM THE CONSTITUTIONAL STRUCTURE}

From the foregoing descriptions of the Stevens and Scalia positions, one thing should be quite clear: Purposivists and textualists start from

breadth." (first alteration in original) (internal quotation omitted)); Pension Benefit Guar. Corp. v. LTV Corp., 496 U.S. 633, 646-47 (1990) (Blackmun, J.) ("“[N]o legislation pursues its purposes at all costs. Deciding what competing values will or will not be sacrificed to the achievement of a particular objective is the very essence of legislative choice-and it frustrates rather than effectuates legislative intent simplistically to assume that whatever furthers the statute's primary objective must be the law." (quoting Rodriguez v. United States, 480 U.S. 522, 525-26 (1987))); Hallstrom v. Tillamook County, 493 U.S. 20,29 (1989) (O'Connor, J.) ("Giving full effect to the words of the statute preserves the compromise struck by Congress."); Cmty. for Creative Non-Violence v. Reid, 490 U.S. 730, 748 n.14 (1989) (Marshall, J.) ("Strict adherence to the language and structure of the Act is particularly appropriate where, as here, a statute is the result of a series of carefully crafted compromises."). Indeed, the Court recently made the same point about state laws in terms suggesting that the Court regards messiness and compromise as an inescapable reality of the legislative process. See Fitzgerald v. Racing Ass'n of Cent. Iowa, 539 U.S. 103, 108 (2003) (noting that the state law under review, "like most laws, might predominately serve one general objective ... . while containing subsidiary provisions that seek to achieve other desirable (perhaps even contrary) ends as well, thereby producing a law that balances objectives but still serves the general objective when seen as a whole"). Accordingly, as many scholars have noted, the Rehnquist Court's approach to statutory interpretation became considerably more textually oriented than in the past. See, e.g., Thomas W. Merrill, Textualism and the Future of the Chevron Doctrine, 72 Wash. U. L.Q. 351, 356-63 (1994) (discussing the Rehnquist Court's shift toward textualism); Peter L. Strauss, On Resegregating the Worlds of Statute and Common Law, 1994 Sup. Ct. Rev. 429, 444-45 (same); Samuel A. Thumma \& Jeffrey L. Kirchmeier, The Lexicon Has Become a Fortress: The United States Supreme Court's Use of Dictionaries, 47 Buff. L. Rev. 227, 252-60 (1999) (same).

The influence of textualism is also evident in the way purposivist Justices now frame their opinions. Consider General Dynamics Land Systems, Inc. v. Cline, 540 U.S. 581 (2004), in which the Court examined whether the Age Discrimination in Employment Act of 1967 ("ADEA"), Pub. L. No. 90-202, 81 Stat. 603 (codified as amended at 29 U.S.C. $\S \S 621-634$ (2000)), prohibits discrimination against younger workers in favor of older ones. In his opinion for the Court, Justice Souter-one of the Court's leading purposivists - found that the Act's protections reach only discrimination against older workers and in favor of younger workers, even though the text unqualifiedly bans "discriminat[ion] . . because of [an] individual's age." 29 U.S.C. § 623(a)(1); see also Cline, 540 U.S. at 585-86. To be sure, he relied centrally on the ADEA's apparent purposes, as evidenced by both the legislative history and the enacted findings of purpose. See id. at 589-93. But the important point is that Justice Souter felt it necessary to show that the phrase "age discrimination" has come to have a colloquial usage that is capable of bearing the narrower meaning:

[T] used the phrase "discriminat[ion] . . . because of [an] individual's age" the same way that ordinary people in common usage might speak of age discrimination any day of the week. One commonplace conception of American society in recent decades is its character as a "youth culture," and in a world where younger is better, talk about discrimination because of age is naturally understood to refer to discrimination against the older.

$I d$. at 591. Accordingly, although he ultimately rested his opinion on inferences of purpose, Justice Souter felt it necessary to justify that result in terms of accepted understandings of the text. At one time not too long ago, the Court might instead have decided Cline by holding that the letter of the ADEA reached discrimination in both directions, but that the spirit of the statute confined its intended reach to discrimination against older workers. That kind of reasoning is now exceedingly scarce in the U.S. Reports. 
diametrically opposed premises. Purposivists (like Justice Stevens) presume that Congress often enacts inadvertently imprecise texts in pursuit of coherent policies. In contrast, textualists (like Justice Scalia) presume that Congress enacts rather precise texts but frequently sacrifices policy coherence as the price of enactment. Neither presumption rests on anything like a reliable empirical judgment about why a statute may have an awkward means/ends fit in any given case. To be sure, textualists believe-in my view, correctly - that because all statutes reflect bargaining among large numbers of actors representing quite diverse interests and views, all laws inevitably embody some measure of bargained-for compromise. But it is quite another thing to suggest that one can tell whether statutory awkwardness in any given case is, in fact, the by-product of phraseology that stemmed from a compromise essential to the bill's passage or, instead, the mere side effect of legislative inadvertence that could and would have been corrected had the specific statutory application come to the legislators' attention. Indeed, for a textualist (like myself), an inescapable starting premise is that the complexity, opacity, and path dependence of the legislative process make it difficult, if not impossible, to know why a statute took the final shape it did or, counterfactually, whether legislators could have successfully amended the statute to deal with a troublesome application had it been foreseen. At times, moreover, even a strong purposivist like Justice Stevens has seemed to acknowledge room for empirical doubt about the reasons a particular piece of legislation may have ended up looking as it did. ${ }^{117}$

Accordingly, a choice between the Stevens presumption of messy drafting but coherent policy and the Scalia presumption of deliberate drafting but messy compromise must rest on a systemic, normatively rooted premise about which of the two presumptions better describes the appropriate judicial understanding of Congress's role in our constitutional structure. Of course the Constitution does not explicitly prescribe rules of statutory interpretation. But because all such interpretation is "an interbranch encounter of sorts,"118 selecting an appropriate interpretive

117. In his famous opinion in Chevron U.S.A. Inc. v. Natural Resources Defense Council, Inc., 467 U.S. 837 (1984), Justice Stevens acknowledged the mysteries of the legislative drafting process. In explaining the Court's decision to equate ambiguity in an administrative statute with a legislative delegation of lawmaking power to the agency, his opinion for the Court offered the following account of why Congress might enact an open-ended administrative statute:

Perhaps [Congress] consciously desired the [agency] to strike the [specific policy] balance ... thinking that those with great expertise and charged with responsibility for administering the provision would be in a better position to do so; perhaps it simply did not consider the question at this level; and perhaps Congress was unable to forge a coalition on either side of the question, and those on each side decided to take their chances with the scheme devised by the agency. For judicial purposes, it matters not which of these things occurred. Id. at 865 .

118. Jane S. Schacter, Metademocracy: The Changing Structure of Legitimacy in Statutory Interpretation, 108 Harv. L. Rev. 593, 593 (1995). 
method involves inevitable choices about the institutional allocation of power between courts and legislatures. ${ }^{119}$ To the extent that our constitutional structure reflects considered judgments about that allocation of power, rules of statutory interpretation should be designed to further, rather than detract from, the structural objectives established by the constitutional design. ${ }^{120}$

119. See id. at 593-94 ("[S]tatutory interpretation represents the legal moment when a court confronts the product of the legislative branch and must assign meaning to a contested provision. To carry out its task, the court must adopt-at least implicitly-a theory about its own role by defining the goal and methodology of the interpretive enterprise and by taking an institutional stance in relation to the legislature."). Jerry Mashaw has made a similar point:

Any theory of statutory interpretation is at base a theory about constitutional law. It must at the very least assume a set of legitimate institutional roles and legitimate institutional procedures that inform interpretation. Otherwise, rudimentary questions, such as whether a particular document presented for interpretation is a statute, or whether the presentation of that document in a particular context calls for an authoritative interpretation of it, cannot be answered. Beyond these very basic questions lie many more that determine ultimately what it means to speak authoritatively in a legislative or in a legal-interpretive voice. Such questions can be answered only by reference to the fundamental normative and institutional attributes of the state.

Jerry Mashaw, As If Republican Interpretation, 97 Yale L.J. 1685, 1686-87 (1988) (emphasis omitted).

120. See, e.g., John F. Manning, Constitutional Structure and Judicial Deference to Agency Interpretations of Agency Rules, 96 Colum. L. Rev. 612, 636-37 (1996) [hereinafter, Manning, Structure and Deference]; John F. Manning, Constitutional Structure and Statutory Formalism, 66 U. Chi. L. Rev. 685, 689-93 (1999). Before turning to the relevant structural inferences, it is necessary to explain why it is even permissible for a textualist to rely on such inferences. After all, drawing structural inferences entails inferring background purpose from the text of the Constitution as a whole. After all, if textualists doubt that one can infer purpose from the complex legislative process, one might think it hopeless to try to derive purpose from the far more complex process of adopting the Constitution. That concern, however, misapprehends both the lessons of modern textualism and what it means to draw structural inferences from the Constitution. Textualists do not deny that a statutory text, read in context, can convey a purpose. See, e.g., W. Va. Univ. Hosps., Inc. v. Casey, 499 U.S. 83, 98 (1991) (Scalia, J.) ("The best evidence of . . purpose is the statutory text adopted by both Houses of Congress and submitted to the President."); see also Manning, supra note 89 , at $2396-98$ (discussing the way texts express intent or purpose). Nor do they deny that the structure of a statutory scheme potentially sheds light on the objectives sought to be advanced. See, e.g., City of Columbus v. Ours Garage \& Wrecker Serv., Inc., 536 U.S. 424, 450 (2002) (Scalia, J., dissenting) (noting that "[e]vidence of pre-emptive purpose is sought in the text and structure of the statute at issue" (alteration in original) (emphasis omitted) (quoting CSX Transp., Inc. v. Easterwood, 507 U.S. 658, 664 (1993)); United States v. Fausto, 484 U.S. 439, 449 (1988) (Scalia, J.) (holding that the non-reviewability of adverse personnel actions under the Civil Service Reform Act derives "not only from the statutory language, but also from ... . the structure of the statutory scheme"). Rather, textualists object to the courts' using background statutory purpose to contradict the clear semantic import of a specific statutory provision. See, e.g., Johnson v. United States, 529 U.S. 694, 723 (2000) (Scalia, J., dissenting) ("Our obligation is to go as far in achieving the general congressional purpose as the text of the statute fairly prescribes-and no further."); Mertens v. Hewitt Assocs., 508 U.S. 248, 261 (1993) (Scalia, J.) ("[V]ague notions of a statute's 'basic purpose' are ... inadequate to overcome the words of its text regarding the specific issue under consideration."). In such cases, modern textualists believe that enforcing the purpose rather than the clear text of a statute potentially undermines legislative 
In this part, I suggest two related reasons for thinking that the textualists' presumption of messy compromise accords better with background understandings of constitutional law. First, because the Constitution lays heavy emphasis on legislative compromise, a presumption in favor of clear semantic import of an enacted text supplies a necessary means by which compromise, once reached, can be effectively recorded. ${ }^{121}$ Ultimately, if courts presume that semantic meaning, when clear, captures an underlying (but unstated) compromise, those who wish to strike a compromise will possess a reliable way of doing so. Conversely, if the Court presumes that awkward wording reflects inadvertence, then it becomes difficult to see how legislators can reliably agree to support legislation on the condition that its supporters will accept half a loaf. Agreed-upon limits on the reach of any statutory rule risk giving way to claims that carrying the statute to its logical conclusion will effectuate the legislative will and correct an obvious failure of legislative expression. Second, a presumption of policy coherence is also in tension with the highly deferential regime of rationality review that the Court applies to evaluate ordinary socioeconomic legislation under the Due Process and Equal Protection Clauses. ${ }^{122}$ Under the rational basis test, courts may not insist that a statute be coherent with an overarching legislative purpose because such insistence would intrude upon the prerogatives of an often messy but ultimately democratic political process. I submit here that the presumption of coherence that lies at the heart of strong purposivism achieves indirectly through statutory

compromise. See, e.g., Barnhart v. Sigmon Coal Co., 534 U.S. 438, 461 (2002) (Thomas, J.) ("Dissatisfied with the text of the statute, the Commissioner attempts to search for and apply an overarching legislative purpose to each section of the statute. Dissatisfaction, however, is often the cost of legislative compromise."); City of Chicago v. Envtl. Def. Fund, 511 U.S. 328,339 (1994) (Scalia, J.) ("It is not unusual for legislation to contain diverse purposes that must be reconciled, and the most reliable guide for that task is the enacted text."). Conversely, when a specific statutory provision is silent or ambiguous on a critical interpretive point, textualists readily consult a statute's overall purpose to resolve the question. See, e.g., Asgrow Seed Co. v. Winterboer, 513 U.S. 179, 192 (1995) (Scalia, J.) ("While the meaning of the text is by no means clear, this is in our view the only reading that comports with the statutory purpose . . .."); Nat'l Tax Credit Partners v. Havlik, 20 F.3d 705, 707 (7th Cir. 1994) (Easterbrook, J.) ("Knowing the purpose behind a rule may help a court decode an ambiguous text, but first there must be some ambiguity." (citations omitted)). Using structural inferences to resolve the textually unspecified question of appropriate interpretive norms surely falls within the constitutional tradition of interpreting open-ended grants of power in light of the constitutional structure as a whole. See Charles L. Black, Structure and Relationship in Constitutional Law 3-32 (1969) (examining the use of structural inference in constitutional adjudication); Henry P. Monaghan, The Supreme Court, 1974 Term-Foreword: Constitutional Common Law, 89 Harv. L. Rev. 1, 13 n.72 (1975) ("[T]he traditional method of 'interpreting' textual provisions is hardly inconsistent with taking into account structural considerations. The former are often simply the textual embodiment of the latter."). In such cases, textualists will consult structural inferences from the text as a whole "not because th[e] precise accommodative meaning is what the lawmakers must have had in mind ...., but because it is [the judiciary's] role to make sense rather than nonsense out of the corpus juris." W. Va. Univ. Hosps., 499 U.S. at 100-01.

121. See infra Part III.A.

122. See infra Part llI.B. 
interpretation what the Court has placed off limits in the context of judicial review. In closing, I will add a few words about the subsidiary debate concerning the use of legislative history as a source of evidence about statutory meaning. ${ }^{123}$

\section{A. Semantic Meaning and Legislative Compromise}

The textualists' systemic presumption that the clear semantic import of the enacted text reflects compromise (rather than judicial correctable legislative inadvertence) fits more comfortably within a constitutional structure that contemplates and, indeed, places a premium on legislative compromise. ${ }^{124}$ As I have discussed in detail in previous writing, ${ }^{125}$ political scientists have shown that by dividing the legislative process among three institutions answering to distinct constituencies, the bicameralism and presentment requirements of Article I, Section 7, in effect create a supermajority requirement. ${ }^{126}$ This feature, in turn, serves to harness the influence of majoritarian "factions" by assigning political minorities extraordinary power to stop (or at least slow) the passage of legislation and, more important, to insist upon compromise as the price of their assent. ${ }^{127}$

123. See infra Part III.C.

124. The discussion that follows builds upon Manning, supra note 91, at 103-05.

125. See Manning, supra note 89, at 2437-38; Manning, supra note 4, at 70-78.

126. See James M. Buchanan \& Gordon Tullock, The Calculus of Consent 233-48 (1962) (explaining the way bicameralism results in supermajority requirements).

127. Indeed, by requiring equal representation of states in the Senate, the Constitution gives quite explicit protection to the political minority consisting of small-state residents. See U.S. Const. art. I, $\S 3$; see also id. art. V (providing that "no State, without its Consent, shall be deprived of its equal Suffrage in the Senate"). For an important discussion of this feature of the Constitution, see Bradford R. Clark, Separation of Powers as a Safeguard of Federalism, 79 Tex. L. Rev. 1321, 1371-72 (2001). This emphasis is reinforced by important rules of legislative procedure adopted by each House. U.S. Const. art. I, $\S 5, \mathrm{cl}$. 2 ("Each House may determine the Rules of its Proceedings."). By erecting many and diverse veto gates, the design of the legislative process betrays a definite bias in favor of the status quo, making it hard for the majority to translate its policy impulses seamlessly into legislation. See Manning, supra note 89, at 2390 ("[L]egislative preferences do not pass unfiltered into legislation; they are distilled through a carefully designed process that requires legislation to clear several distinct institutions, numerous veto gates, the threat of a Senate filibuster, and countless other procedural devices that temper unchecked majoritarianism."). Some legislative procedures-most notably, Senate rules concerning the filibuster and requirements of unanimous consent-quite obviously seek to protect minority interests. See, e.g., Kenneth A. Shepsle \& Barry R. Weingast, The Institutional Foundations of Committee Power, 81 Am. Pol. Sci. Rev. 85, 89 (1987) ("A small group of senators in the U.S. Senate may engage in filibuster and other forms of obstruction. Any individual senator may refuse unanimous consent to procedures that would expedite passage of a committee bill. In short, veto groups are pervasive in legislatures . . .."). Other procedures - such as the requirement of committee approval-are somewhat more ambiguous, but potentially have a similar effect. Although political scientists debate the question rather vigorously, a good deal of evidence supports the view that many standing committees are imperfectly representative of the chamber from which they are drawn. See, e.g., John R. Boyce \& Diane P. Bischak, The Role of Political Parties in the Organization of Congress, 18 J.L. Econ. \& Org. 1, 2-3 (2002) (summarizing the debate). The conclusions drawn here do not depend on 
Judicial adherence to clear semantic meaning is crucial to effectuating the compromises that the constitutional structure produces. Semantic meaning uniquely affords legislators a means to express the level of generality at which they wish to articulate the policies to which they have agreed. As discussed, legislators may wish to accept half a loaf. Or they may agree to forgo costly and disruptive bargaining over desired exceptions to otherwise broadly framed statutory terms. ${ }^{128}$ Semantic meaning provides the most, if not the only, reliable means by which legislators can express the relevant limits on how far they are willing to go. If interpreters hew closely to the way a reasonable person would understand language in context, then legislative drafters can convey policy impulses with greater or lesser degrees of specificity. Conversely, if one were to give background purpose priority over semantic detail, then it would be quite difficult to fathom how a legislator with the power to exact a compromise could bargain reliably for any particular outcome.

None of the foregoing analysis is meant to deny that statutory wording may, at times, reflect the random, mistaken, or shortsighted act of a legislative drafter. But the important point is that if a sentient actor with the power to insist upon compromise wishes to agree to legislation based on limiting conditions, he or she must reach an agreement that records those limitations in semantic expression that the relevant linguistic community understands. ${ }^{129}$ If, however, courts are free to abstract from such wording to the statute's apparent background purposes even when the semantic import is clear from context, then it becomes difficult to see how legislators bent on framing their policies in broader or narrower terms can reliably effectuate that goal. Professor Max Radin wrote that seeking a statute's "ultimate" purpose is an unreliable approach to statutory interpretation because "nearly every end is a means to another end," and the purpose of a statute can therefore reasonably be described at many levels of generality. 130 If, as Justice Scalia has suggested, "[t]he final form of a

whether such committees are representative. Accordingly, I leave that complex question to one side for purposes of this Essay.

128. See Manning, supra note 89, at 2424-29 (discussing the process of bargaining over exceptions)

129. Certainly, in cases in which wording reflects happenstance, there will be social costs associated with enforcing the directive as written rather than adjusting it to reflect more accurately the apparent legislative aims. But given the previously discussed difficulties associated with reconstructing the outcomes of a complex legislative process, the opposite strategy-sacrificing semantic integrity for policy coherence-would avoid that cost only by undermining the effective capacity to reduce policy impulses to reliable compromises. To strike that balance would reflect an odd understanding of the concept of legislative supremacy, given the central place that legislative compromise occupies in the design both of bicameralism and presentment and of legislatively adopted rules that, if anything, accentuate the impulses for compromise embodied in the constitutional process.

130. Max Radin, Statutory Interpretation, 43 Harv. L. Rev. 856, 876 (1930). Judge Stephen Williams made a similar point:

Notice that as soon as the analysis of purpose is divorced from the means selected, all limits are off. Every purpose can always be restated at a higher level of generality. We can go straight from protecting consumers to the ultimate 
statute . . . is often the result of a compromise among various interest groups, resulting in a decision to go so far and no farther," 131 then legislators with the authority to exact a compromise must be able to use words to specify just how far that decision has gone.

\section{B. Rationality Review and Statutory Coherence}

The premises underlying rationality review also support the presumption that awkward legislation reflects untidy compromise rather than coherent but poorly drafted policy making. The Court applies the highly deferential rational-basis test when it reviews ordinary legislation (that which does not contain invidious classifications or touch on fundamental rights) under the Due Process and Equal Protection Clauses. ${ }^{132}$ The rational-basis case law makes clear that in such cases the Court's task is to accept legislation if any conceivable rational basis supports it. This highly deferential standard acknowledges that laws may be over- or under-inclusive in relation to their background justifications. In the context of this case law, the Court has made clear that it will not insist upon coherent expressions of policy but will accept as constitutionally permissible the kind of imperfect classifications, rough accommodations, and uneven compromises that the legislative process routinely produces. ${ }^{133}$ This highly deferential standard, moreover, consciously embodies a doctrine of judicial restraint-a way to ensure that judges do not intrude upon the prerogatives of the duly elected political branches. The rationality cases direct courts to bend over backwards to respect imperfect legislation, so that judges do not substitute

weapon-enhancing human dignity. Once you're enhancing human dignity, the range of policy choices is limitless.

Stephen F. Williams, Rule and Purpose in Legal Interpretation, 61 U. Colo. L. Rev. 809, 811 (1990).

131. E. Assoc. Coal Corp. v. United Mine Workers of Am., 531 U.S. 57, 68-69 (2000) (Scalia, J., concurring in the judgment); see also, e.g., Hrubec v. Nat'l R.R. Passenger Corp., 49 F.3d 1269, 1270 (7th Cir. 1995) (Easterbrook, J.) ("Many laws are compromises, going thus far and no further in pursuit of a goal."); Heath v. Varity Corp., 71 F.3d 256, 258 (7th Cir. 1995) (Easterbrook, J.) ("Legislation reflects compromise among competing interests .... It upsets the legislative balance to push the outcome farther in either direction."); Easterbrook, supra note 102, at 63 ("[L]aw is like a vector. It has length as well as direction. We must find both, or we know nothing of value. To find length we must take account of objectives, of means chosen, and of stopping places identified."); Easterbrook, Foreword, supra note 105, at 46 ("If legislation grows out of compromises among special interests, ... a court cannot add enforcement to get more of what Congress wanted. . . . When a court observes that Congress propelled Group $\mathrm{X}$ part way to its desired end, it cannot assist Group $\mathrm{X}$ farther along the journey without undoing the structure of the deal.").

132. The analysis of rationality review draws upon Manning, supra note 89, at 2446-54.

133. See, e.g., U.S. R.R. Ret. Bd. v. Fritz, 449 U.S. 166, 175 (1980) ("[T]he Court in cases involving social and economic benefits has consistently refused to invalidate on equal protection grounds legislation which it simply deemed . . . unartfully drawn."); Flemming v. Nestor, 363 U.S. 603, 611 (1960) ("[I]t is not within our authority to determine whether the Congressional judgment . . . is sound or equitable . . .."); Williamson v. Lee Optical Co., 348 U.S. 483, 488 (1955) (noting that courts lack authority to displace legislation simply because they think it "unwise, improvident, or out of harmony with a particular school of thought"). 
their judgment for that of the (unruly) democratic process. In other words, were the courts to insist that legislation be coherent with some overarching purpose, whether actual or hypothesized, then judicial review would displace a great deal of legislative policy making. I argue here that the presumption of legislative coherence imposed by strong purposivism allows federal courts to achieve indirectly what the Court has forbidden them to accomplish directly through judicial review.

Although the Court's decisions have varied somewhat in their approach to rationality review, ${ }^{134}$ it is fair to say that the dominant theme of the Court's post-New Deal cases has been one of exceptional deference toward ordinary legislation - whether state or federal and whether challenged under due process or equal protection principles. The Court attaches a powerful presumption of validity to statutes that do not employ suspect classifications or affect fundamental rights. ${ }^{135}$ In such cases, the Court (with rare exception) has refused to consider the legitimacy of legislative ends. ${ }^{136}$ More important for present purposes, the Court has also rejected the requirement of a substantial means-ends fit. ${ }^{137}$

The process assumptions underlying rationality review are instructive in deciding whether to embrace the purposivists' presumption that legislation is (a) ultimately coherent with an overarching background purpose and (b) ripe for judicial adjustment if the clear import of the text fails to capture the presumed standard of coherence. First, the rational-basis case law explicitly presupposes that a well-functioning legislative process will produce imperfect, if not odd, statutes as a matter of course (rather than as a matter of imprecise drafting). The Court has thus emphasized that "[ $t]$ he problems of government are practical ones and may justify, if they do not require, rough accommodations-illogical, it may be, and unscientific."'138

134. See Fritz, 449 U.S. at 176 n. 10 (emphasizing that " $[\mathrm{t}]$ he most arrogant legal scholar would not claim that all of [the Court's] cases applied a uniform or consistent test" of rationality); see also Cent. State Univ. v. Am. Ass'n of Univ. Professors, 526 U.S. 124, 132 (1999) (Stevens, J., dissenting) ("Cases applying the rational-basis test have described that standard in various ways.").

135. See, e.g., Hodel v. Indiana, 452 U.S. 314, 331-32 (1981) (stating that "such legislation carries with it a presumption of rationality that can only be overcome by a clear showing of arbitrariness and irrationality"); Lehnhausen v. Lake Shore Auto Parts Co., 410 U.S. 356, 364 (1973) ("The burden is on the one attacking the legislative arrangement to negative every conceivable basis which might support it." (quoting Madden v. Kentucky, 309 U.S. 83, $88(1940))$ ).

136. See Henry P. Monaghan, Marbury and the Administrative State, 83 Colum. L. Rev. 1, 34 (1983) (noting that rationality review provides, "as a matter of constitutional interpretation, that the political branches are empowered to achieve a broad range of goals").

137. Cass R. Sunstein, Naked Preferences and the Constitution, 84 Colum. L. Rev. 1689, 1697-98 (1984) ("Modern rationality review is also characterized by extremely deferential means-ends scrutiny. The Supreme Court demands only the weakest link between a public value and the measure in question, and it is sometimes willing to hypothesize legitimate ends not realistically attributable to the enacting legislature.").

138. Dandridge v. Williams, 397 U.S. 471, 485 (1970) (quoting Metropolis Theatre Co. v. City of Chicago, 228 U.S. 61, 69-70 (1913)); see also, e.g., City of Dallas v. Stanglin, 490 U.S. 19, 27 (1989); Vance v. Bradley, 440 U.S. 93, 108 n.26 (1979). 
Further, the legislative process "often involves tradeoffs, compromises, and imperfect solutions." 139 Legislation, in other words, will not always reflect a coherent expression of public policy.

Second, modern rationality review insists that the judiciary respect these "imperfect" legislative outcomes. ${ }^{140}$ The rationality cases, moreover, rest on a conscious judgment about the appropriate limits on judicial power in our system of government-or, more accurately, the appropriate line to be drawn between judicial and legislative power in that system. The judiciary lacks " "authority to determine whether [a] Congressional judgment . . . is sound or equitable, or whether it comports well or ill with purposes of the Act."'141 Rather, in cases of routine legislation, the judiciary "properly exercises only a limited review power over Congress, the appropriate representative body through which the public makes democratic choices among alternative solutions to social and economic problems." 142 In other words, rationality review "is a paradigm of judicial restraint."143

Accordingly, the judiciary must sustain ordinary legislation "if there is any reasonably conceivable state of facts that could provide a rational basis for the classification." 144 If the Court can identify "plausible reasons" for Congress's action, judicial "inquiry is at an end." 145 And it is "entirely

139. Preseault v. Interstate Commerce Comm'n, 494 U.S. 1, 19 (1990).

140. In this sense, the modern cases admirably reflect the premises of Justice Oliver Wendell Holmes's famous dissent in Lochner v. New York, 198 U.S. 45 (1905), in which he wrote that "[the Constitution] is made for people of fundamentally differing views, and the accident of our finding certain opinions natural and familiar or novel and even shocking ought not to conclude our judgment upon the question whether statutes embodying them conflict with the Constitution of the United States." Id. at 76 (Holmes, J., dissenting). Justice Hugo Black's majority opinion in Ferguson v. Skrupa, 372 U.S. 726 (1963), describes the Court's shift to Holmes's position:

There was a time when the Due Process Clause was used by this Court to strike down laws which were thought unreasonable, that is, unwise or incompatible with some particular economic or social philosophy....

$\cdots$

The doctrine that prevailed in ... [such] cases-that due process authorizes courts to hold laws unconstitutional when they believe the legislature has acted unwisely-has long since been discarded.

Id. at 729-30. For an excellent summary of the consolidation of the Court's post-New Deal framework, see Robert A. McCloskey, Economic Due Process and the Supreme Court: An Exhumation and Reburial, 1962 Sup. Ct. Rev. 34, 38.

141. U.S. R.R. Ret. Bd. v. Fritz, 449 U.S. 166, 175-76 (1980) (quoting Flemming v. Nestor, 363 U.S. 603, 611 (1960)); see, e.g., Hodel, 452 U.S. at 333 (noting that a federal court "exceed[s] its proper role" if it passes on the wisdom of legislation); City of New Orleans v. Dukes, 427 U.S. 297, 303 (1976) (stating that federal courts lack authority to "judge the wisdom or desirability of legislative policy determinations made in areas that neither affect fundamental rights nor proceed along suspect lines"); Ferguson, 372 U.S. at 730 (endorsing the proposition "that courts do not substitute their social and economic beliefs for the judgment of legislative bodies, who are elected to pass laws").

142. Schweiker v. Wilson, 450 U.S. 221, 230 (1981).

143. FCC v. Beach Commc'ns, Inc., 508 U.S. 307, 314 (1993).

144. Id. at 313; see also, e.g., Sullivan v. Stroop, 496 U.S. 478, 485 (1990); Bowen v. Gilliard, 483 U.S. 587, 600-03 (1987); Fritz, 449 U.S. at 174-79; Dandridge v. Williams, 397 U.S. 471, 484-85 (1970).

145. Fritz, 449 U.S. at 179. 
irrelevant for constitutional purposes whether the conceived [rational basis] ... actually motivated the legislature."146 This focus on outcome, rather than intent, follows from the Court's acceptance of the imperfections of the legislative process. If legislation often represents a rough compromise, then measuring it against "actual" legislative purpose risks attributing unwarranted coherence to a process that "may entail logrolling or other strategic voting, making concessions to strongly felt but outlying interests, or papering over disagreements to ensure the legislation's passage."147 To respect an inherently unruly legislative process, judges applying the rational-basis test must focus only on the rationality of the legislative outcomes, not on whether those outcomes further some actual legislative purpose. ${ }^{148}$

The strong purposivism employed by Justice Stevens to interpret statutes starts from quite different presumptions. If a statutory classification, although clearly expressed, contradicts the apparent purpose that can be pieced together from contextual evidence, then judges are warranted in revising the clear statute on the assumption that Congress would have done so itself had the problem come to its attention. If the complexity, opacity, and path dependence of the legislative process make such a conclusion impossible to substantiate empirically in any given case, then Justice Stevens's approach, in effect, authorizes judges to displace clearly expressed statutory commands through interpretation (rather than judicial review) based on a systemic legal (rather than factual) presumption of legislative coherence. That presumption, however, itself contradicts the clear message of the rationality cases: Legislatures sometimes, if not often, draw awkward lines of compromise, but those outcomes nonetheless merit judicial respect in our system of constitutional democracy. Because drawing lines of statutory inclusion and exclusion is "peculiarly a legislative task" for which "“[p]erfection ... is neither possible nor

146. Beach Commc'ns, 508 U.S. at 315 ; see also, e.g., Nordlinger v. Hahn, 505 U.S. 1,15 (1992) (holding that "rational-basis review" does not require "that a legislature or governing decisionmaker actually articulate at any time the purpose or rationale supporting its classification"); Fritz, 449 U.S. at 179 (noting that it is "constitutionally irrelevant whether [the proffered rational basis] in fact underlay the legislative decision"" (quoting Flemming, 363 U.S. at 612)).

147. Manning, supra note 89 , at 2450.

148. In Fritz, the Court rejected the argument that a statutory classification was irrational because "Congress was unaware of what it accomplished or ... was misled by the groups that appeared before it." Fritz, 449 U.S. at 179. The Court emphasized as follows:

If this test were applied literally to every member of any legislature that ever voted

on a law, there would be very few laws which would survive it. The language of the statute is clear, and we have historically assumed that Congress intended what it enacted. To be sure, [the party challenging the statute] lost a political battle in which he had a strong interest, but this is neither the first nor the last time that such a result will occur in the legislative forum.

Id.; see also Vance v. Bradley, 440 U.S. 93, 109 (1979) (stating that it is "irrelevant" whether the Court believes that "Congress was unwise in not choosing a means more precisely related to its primary purpose"). 
necessary," "149 a court must give effect to a rational classification even if it is "to some extent both underinclusive and overinclusive" in relation to its apparent purpose. ${ }^{150}$ Judges who practice strong purposivism rely on statutory interpretation to achieve indirectly what the rationality case law prevents them from achieving directly through judicial review-namely, correcting problems of means/ends fit that the rational-basis test selfconsciously instructs judges to accept as part of the messy reality of legislative governance. ${ }^{151}$

\section{A Brief Note on Legislative History}

A purposivist such as Justice Stevens might suggest that if textualists are ultimately concerned with preserving legislative compromise, they should not hesitate to seek evidence of its terms in the legislative history, which after all records the internal deliberations leading to enactment. And it does not suffice to respond, as textualists often do, that legislators (and the lobbyists who seek to influence them) now salt the legislative history with statements that are expressly calculated to influence judges - a phenomenon that presumably makes such "history" an unreliable record of genuine legislative understanding or deliberation. ${ }^{152}$ The textualists' position is at

149. Schweiker v. Wilson, 450 U.S. 221, 234 (1981) (quoting Mass. Bd. of Ret. v. Murgia, 427 U.S. 307, 314 (1976)). Indeed, such line-drawing "'inevitably requires that some persons who have an almost equally strong claim to favored treatment be placed on different sides of the line, and the fact [that] the line might have been drawn differently at some points is a matter for legislative, rather than judicial, consideration." Fritz, 449 U.S. at 179 (citation omitted) (quoting Mathews v. Diaz, 426 U.S. 67, 83-84 (1976)).

150. Vance, 440 U.S. at 108 .

151. One might argue that strong purposivism does not contradict the rational-basis case law because the former involves statutory interpretation rather than judicial review. But it is unclear whether aggressive interpretation, in fact, poses any less of a risk of institutional intrusion by the judiciary upon the legislative process. Professor Mashaw has shown that misconstruction of a statute intrudes more obviously on legislative prerogatives than does striking down an unconstitutional statute. See Jerry L. Mashaw, Greed, Chaos, and Governance: Using Public Choice to Improve Public Law 105 (1997). If the Court displaces a legislative classification by invalidating a statute, that action returns matters to the pre-statute status quo. The legislature may reenact a similar policy, since the process of reenactment requires bargaining among the three actors (the House, the Senate, and the President) who passed the original bill. See id. If the Court instead alters a statutory text through interpretation, that result will stick if any of the three actors prefers it to the likely corrective legislation. See id. at 102-03.

152. See, e.g., United States v. Taylor, 487 U.S. 326, 345 (1988) (Scalia, J., concurring in the judgment) (suggesting that the entrenched practice of judicial reliance on legislative history had produced a "legal culture" in which a legislator might simply offer strategic legislative history in place of a statutory amendment); Int'l Bhd. of Elec. Workers, Local Union No. 474 v. NLRB, 814 F.2d 697, 717 (D.C. Cir. 1987) (Buckley, J., concurring) (" $[\mathrm{T}] \mathrm{o}$ the degree that judges are perceived as grasping at any fragment of legislative history for insights into congressional intent, to that degree will legislators be encouraged to salt the legislative record with unilateral interpretations of statutory provisions they were unable to persuade their colleagues to accept."); Note, Why Learned Hand Would Never Consult Legislative History Today, 105 Harv. L. Rev. 1005, 1015-19 (1992) (contending that legislative knowledge of the interpretive authority of legislative history necessarily cornupts the legislative record with strategic statements calculated to influence judges). 
least open to empirical debate. Recent political science scholarship, for example, suggests that those actors who produce (what courts have long regarded as) the most authoritative legislative history-committee reports and sponsors' statements - speak as agents of the legislative majority. ${ }^{153}$ On this assumption, because legislators are repeat players, if a committee chair or sponsor does not accurately describe the aims of the enacting coalition, he or she "can be subject to sanctions and loss of reputation."154 More generally, thoughtful analysts of the legislature have argued that even if legislators now strategically shape legislative history to flesh out statutory details, the contents of such history nonetheless reflect the product of legislative negotiation and, for that reason, lend insight into the underlying compromise. ${ }^{155}$

In prior writing, I have extensively discussed the problem of legislative history. ${ }^{156}$ Although I will not rehearse that analysis here, brief consideration of the legislative history problem is warranted for completeness. The foregoing observations about the production of legislative history do not suffice to overcome structural or practical concerns about the legitimacy of such material as an interpretive tool, particularly when courts rely on it to overcome the clear semantic import of the statutory text. First, if courts rely on legislative history because it represents an authoritative (if not enacted) articulation of policy detail by designated agents of the majority (a form of non-text text, as it were), ${ }^{157}$ the rationale for that practice would contradict deeply ingrained constitutional norms against self-delegation. ${ }^{158}$ Well-settled constitutional precedents afford Congress wide latitude to delegate law-elaboration authority to the

153. Professors Matthew D. McCubbins, Robert Noll, and Barry R. Weingast (who publish collectively under the name McNollgast) contend that committee chairs and floor managers explain legislative intent or purpose as "appointed agent[s] of the legislative majority that passed the chamber's version of the statute." McNollgast, Legislative Intent: The Use of Positive Political Theory in Statutory Interpretation, Law \& Contemp. Probs., Winter 1994, at 3, 24.

154. Id.

155. See, e.g., Stephen Breyer, On the Uses of Legislative History in Interpreting Statutes, 65 S. Cal. L. Rev. 845, 858-59 (1992) (arguing that in striking compromises, legislators, their staffs, and other participants in the legislative process negotiate about not only the statutory text, but also the content of legislative reports and floor statements); Daniel B. Rodriguez \& Barry R. Weingast, The Positive Political Theory of Legislative History: New Perspectives on the 1964 Civil Rights Act and its Interpretation, $151 \mathrm{U}$. Pa. L. Rev. 1417, 1432 (2003) ("Statutes-including both the text of the enacted law and the legislative 'history' encoded into the public record of the statute-reflect not only legislative specialization and expertise, but the vitally important object of trade and negotiation.").

156. See John F. Manning, Textualism as a Nondelegation Doctrine, 97 Colum. L. Rev. 673 (1997).

157. For a particularly thoughtful defense of legislative history as an extension of the adopted text, see Jonathan R. Siegel, The Use of Legislative History in a System of Separated Powers, 53 Vand. L. Rev. 1457 (2000).

158. The discussion that follows builds on Manning, supra note 156 , at $706-25$ (discussing the norm against self-delegation and its applicability to judicial reliance on legislative history as an authoritative source of meaning). 
coordinate branches, ${ }^{159}$ but not to its own agents or members. ${ }^{160}$ In other words, Congress has the choice of "formulat[ing] the details" of statutory policy itself or "assign[ing] to the Executive Branch the responsibility" for doing so; it may not assign that authority to those under its direct control. ${ }^{161}$ The justification for drawing such a line is straightforward. If Congress can delegate law-elaboration authority only to the coordinate branches, its choice to do so incurs the structurally induced cost of ceding control over policy detail to its constitutional rivals. ${ }^{162}$ If, however, Congress can delegate the formulation of statutory detail to its agents under its direct control, that important structural disincentive against delegation is compromised. Indeed, Justice Stevens has acknowledged as much (in a context other than the use of legislative history):

If Congress were free to delegate its policymaking authority to one of its components, or to one of its agents, it would be able to evade "the carefully crafted restraints spelled out in the Constitution." That dangercongressional action that evades constitutional restraints [of bicameralism and presentment]-is not present when Congress delegates lawmaking power to the executive or to an independent agency. ${ }^{163}$

This constitutional understanding, I believe, makes it quite difficult to justify legislative history as an authoritative (but unenacted) elaboration of statutory detail by agents empowered by the legislative majority to act on its behalf. ${ }^{164}$

159. The Court has repeatedly sustained broad delegations of law-elaboration to administrative agencies. See, e.g., Whitman v. Am. Trucking Ass'ns, 531 U.S. 457, 474-75 (2001) ("[W]e have "almost never felt qualified to second-guess Congress regarding the permissible degree of policy judgment that can be left to those executing or applying the law." (quoting Mistretta v. United States, 488 U.S. 361, 416 (1989) (Scalia, J., dissenting))); Lichter v. United States, 334 U.S. 742, 785-86 (1948) (upholding a delegation authorizing an administrative agency to recoup "excessive profits" on war contracts); Am. Power \& Light Co. v. SEC, 329 U.S. 90, 105 (1946) (holding that the Securities and Exchange Commission may reject corporate reorganizations that are not fair and equitable); NBC v. United States, 319 U.S. 190, 226-27 (1943) (sustaining the Federal Communication Commission's delegated authority to allocate broadcasting licenses in "the public interest, convenience, and necessity").

160. See Metro. Wash. Airports Auth. v. Citizens for the Abatement of Aircraft Noise, Inc. (MWAA), 501 U.S. 252, 274-75 (1991) (individual Members of Congress may not serve on tribunals exercising delegated power); Bowsher v. Synar, 478 U.S. 714, 726-27 (1986) (Congress may not reserve power to remove an officer exercising delegated lawmaking authority); INS v. Chadha, 462 U.S. 919, $944-59$ (1983) (one-House legislative veto is unconstitutional).

161. $M W A A, 501$ U.S. at 272.

162. One can find early recognition of this structural insight in the works of influential theorists such as Montesquieu and Blackstone. See Manning, Structure and Deference, supra note 120, at 647-48 (discussing their separation of powers theories).

163. Bowsher, 478 U.S. at 755 (Stevens, J., concurring) (footnote omitted) (quoting Chadha, 462 U.S. at 959).

164. Professor Jonathan Siegel has argued that if legislative history is available prior to the final vote in both houses, prevailing interpretive conventions (at least, those prevailing prior to the advent of textualism) have made it clear that voting for the bill is tantamount to voting for the authoritative forms of legislative history that accompanied the bill. See Siegel, supra note 157, at 1489-1505. As I have argued elsewhere, that argument does not mitigate 
Second, even if (in contrast with textualists) one considered legislative history as a potentially reliable source of evidence about what compromises legislators actually struck during the legislative process, ${ }^{165}$ it is difficult to see why such history reflects more reliable evidence of the ultimate compromise than would the clear import of the adopted text. The most authoritative forms of legislative history-committee reports and sponsors' statements-are themselves a form of semantic expression. Moreover, where such materials squarely address a difficult interpretive question that later comes before the courts, it necessarily follows that someone in the legislative process has identified that issue before the statute's final adoption. ${ }^{166}$ If the legislative history includes a policy formulation that contradicts the clear import of the adopted text, that fact suggests, if anything, that the alternative formulation could not have survived the rigors of the legislative process. ${ }^{167}$ In other words, if different lines of compromise are suggested by the enacted text and by the unenacted materials, it is hard to justify giving precedence to the latter rather than the former. 168

concerns about self-delegation. See John F. Manning, Putting Legislative History to a Vote: A Response to Professor Siegel, 53 Vand. L. Rev. 1529 (2000). Rather, as explained in greater detail below, there is little reason to suppose that legislators would place a needed clarification in the legislative history rather than the text unless it was more politically or procedurally costly to resort to the latter. Accordingly, from the standpoint of legislators, one cannot easily claim that recording "compromises" in the legislative history is equivalent to recording them in the statute. If legislators rely on extra-statutory utterances by committee chairs or sponsors because it is less politically or procedurally costly to do so, it is inaccurate as a matter of process to equate the statements made by such agents with the texts that have survived bicameral passage and presentment to the President. See id. at 1538-40 (suggesting reasons why Professor Siegel's proposal does not allay concerns about the use of legislative history to circumvent bicameralism and presentment).

165. See, e.g., James M. Landis, A Note on "Statutory Interpretation," 43 Harv. L. Rev. 886,888 (1930) ("The records of legislative assemblies once opened and read with a knowledge of legislative procedure often reveal the richest kind of evidence.").

166. See Manning, supra note 156 , at 728.

167. See, e.g., Manning, supra note 89 , at $2424-31$ (offering examples of legislative history that may have declared intentions that differed from the enactable preferences of Congress as a whole); Vermeule, supra note 13, at 1841-51 (arguing that Congress was unable to make alterations to the Alien Contract Labor Act that the legislative history had equated with the meaning of the Act).

168. Consider an example discussed by then-Judge Stephen G. Breyer in his influential Roth Lectures at the University of Southern California. See Breyer, supra note 155, at 85051. In United States v. Falvey, 676 F.2d 871 (1st Cir. 1982), the court of appeals construed a federal statute imposing criminal penalties upon any person who "possesses . . . any false, forged, or counterfeit coin . . . with intent to defraud . . . any person." 18 U.S.C. $\S 485$, para. 2 (1982). In particular, the court confronted the question whether that provision applies to a coin that is not used as currency within the United States, such as the gold coin of another country purchased as an investment. The possession provision did not itself include any element requiring that the counterfeit coin be United States currency. But another paragraph of the same statute imposes criminal sanctions on anyone who "falsely makes . . . any coin ... in resemblance or similitude of any foreign gold or silver coin current in the United States or in actual use and circulation as money within the United States." Id. $\S 485$, para. 1 . As discussed, see supra text accompanying notes 46, 66-67, a standard interpretive presumption is that when "Congress includes particular language in one section of a statute 


\section{CONCLUSION}

At present, Justice Stevens is the only member of the Supreme Court who openly subscribes to the strong form of purposivism associated with the Court's landmark decision in Holy Trinity. He sees the legislative process as more than rational (in the constitutional sense); he sees it as a process likely to produce quite reasonable and coherent outcomes when measured against the apparent purposes sought to be achieved and the common sense of humankind. When the enacted text falls sufficiently short of that expectation, he frequently assumes that Congress must have misspoken in expressing its policies. For him, Congress is quite coherent in policy formulation but quite messy in its expression. Justice Scalia, in contrast, believes that statutes frequently rest upon undetectable compromises. $\mathrm{He}$ accordingly believes that the only legitimate way to implement Congress's handiwork is to give effect to the details of the enacted text when that text is clear in its semantic context. For him, the legislative process should be presumed to be quite messy in policy formulation, but quite deliberate in its expression of what has been agreed upon by the majority in the process prescribed for legislation.

Because neither presumption ultimately has a meaningful empirical basis for finding that an awkward means/ends reflects either compromise or inadvertence in any given case, the best one can do in choosing between them is to select the presumption that accords more fully with the background assumptions that emanate from the constitutional structure. Two considerations favor that textualist presumption of deliberately drafted but untidy compromise. First, because the lawmaking structure prescribed

but omits it in another section of the same Act, it is generally presumed that Congress acts intentionally and purposely in the disparate inclusion or exclusion." Russello v. United States, 464 U.S. 16, 23 (1983) (quoting United States v. Wong Kim Bo, 472 F.2d 720, 722 (5th Cir. 1972)). Accordingly, in contrast with the falsely making provision, the semantic meaning of the possession provision cannot be read to require proof that the counterfeit coin is in use as currency. Despite the foregoing semantic clarity, then-Judge Breyer argued that the omission of a currency element from the possession provision constituted a drafting error. See Breyer, supra note 155 , at 851 . Prior to a 1965 reorganization of the counterfeiting statute, both the possession and falsely making offenses had been part of the same paragraph, and both had been subject to the qualifier that the relevant offenses apply only to coins used as currency in the United States. See id. at 850. The court of appeals reasoned that when Congress broke out possession as a separate offense, it accidentally dropped the qualifier. See id. Judge Breyer found that conclusion to be warranted based on his reading of the accompanying committee reports, which in his view provided "fairly clear answers" to the interpretive question. Id. at 851 . He thus explained as follows:

[The reports] specify that the congressional reenactment of the law, reorganizing it and rewriting some of it, was intended to serve purely organizational objectives. They say that Congress expected, after the changes, that the law would remain what it was before the changes.... The reports thereby indicate that no one in Congress intended to change substantive law or to rewrite federal counterfeiting law so that it helped protect the currency of all nations .... .

$I d$. Even assuming that the legislative history spoke as decisively as Judge Breyer suggested, it is not apparent why a court should give precedence to clear legislative history rather than the clear import of the agreed-upon statutory text. 
by Article I quite plainly evinces the purpose to protect political minorities by giving them extraordinary power to insist upon compromise, a constitutionally appropriate theory of interpretation should facilitate, rather than thwart, the ability of legislative stakeholders to reduce their bargainedfor compromises to effective written agreements. By converting hardedged rules into open-ended standards, strong purposivism undermines that capacity. Second, the presumption of coherence that underlies Justice Stevens's strong purposivism is in significant tension with the constitutional premises underlying the rational-basis test, which presupposes that legislatures typically adopt rough-hewn compromises and that courts in our system must respect those outcomes if minimally rational. Otherwise, judges risk substituting their own preferences for the unruly but democratic preferences of the legislature. In the past two decades, the Court has begun to embrace the foregoing premises and to move away from the strong purposivism that prevailed when Justice Stevens first took his seat three decades ago. 